\title{
Crafting Idiosyncrasies. Early Social Complexity, Ivory and Identity-Making in Copper Age Iberia
}

\author{
Miriam Luciañez-Triviño ๑, Leonardo García Sanjuán ๑ \& \\ Thomas Schuhmacher
}

\begin{abstract}
As a raw material, ivory has been used to manufacture a wide range of objects, normally associated with sumptuous material culture. In this article we explore the role played by ivory and ivory artefacts among early complex societies, and particularly its importance in the definition of identities among emergent elites. To this end, we make a thorough examination of the evidence from Copper Age Iberia, focusing on the mega-site of Valencina, in southern Spain. This site has provided what to date is the largest assemblage of prehistoric ivory in western Europe, with an estimated total of $8.8 \mathrm{~kg}$, including finely crafted artefacts of unrivalled beauty and sophistication. Our study looks carefully at the technological, morphological and contextual dimensions of Copper Age ivory. As a result, we contend that the broad morphological variability together with the technological uniformity of this assemblage suggest that, while belonging to a common technological tradition, objects were deliberately crafted as unique and unrepeatable so that they could be used to create and maintain socio-cultural idiosyncrasies and ideological legitimation.
\end{abstract}

\section{Introduction}

Ivory is a special raw material, with a long history going back to at least the Upper Palaeolithic (c. 43,000-9700 BC, according to Walker et al. 2009) when it was used to make elaborate ornaments as well as remarkable zoomorphic and anthropomorphic (mostly female) figurines (e.g. Schwab \& Vercoutère 2018; Wolf \& Heckel 2018). Historically, it has been used to manufacture a wide range of mostly sumptuous objects, ranging from personal ornaments (bracelets, necklaces, combs), to art (sculpture, furniture) and a plethora of other artefacts, such as parts of musical instruments. Combined with its aesthetic and cultural appeal, its physical properties, which render it fairly resistant to diagenetic processes, make ivory a unique indicator in the study of ancient crafts, arts, exchange and socio-cultural organization.
But what exactly is ivory? This term is often used to designate different types of large teeth in large mammals (as in the case of the hippopotamus: Ilan 2013; Krzyszkowska 1984; Tournavitou 1995), but in the vast majority of the literature, it is more specifically understood as synonymous with the dentine of the incisors evolved as tusks of the proboscideans and their evolutionary relatives, such as Elephas (Palaeoloxodon) antiquus, Mammuthus, etc., and not the rest of their teeth. In this paper, we will use the term in this sense. In the case of elephants, ivory is obtained from the second upper incisors in continuous growth (Virág 2012, 1406), called 'tusks'. The dental formula is $1 / 0,0 / 0,3 / 3,3 / 3$. The upper incisor that remains on each side is the second (I2), which is replaced by the permanent tooth between 6 and 12 months of age when it is only about $5 \mathrm{~cm}$ long (Feldhamer et al. 1999, 314).

Cambridge Archaeological Journal 32:1, 23-60 C The Author(s), 2021. Published by Cambridge University Press on behalf of the McDonald Institute for Archaeological Research. This is an Open Access article, distributed under the terms of the Creative Commons Attribution-NonCommercial-NoDerivatives licence (http://creativecommons.org/licenses/by-nc-nd/4.0/), which permits non-commercial re-use, distribution, and reproduction in any medium, provided the original work is unaltered and is properly cited. The written permission of Cambridge University Press must be obtained for commercial reuse or in order to create a derivative work. 
Ivory lies at the core of research on exotic resources in Iberian prehistory. Since the end of the nineteenth century and throughout the twentieth, ivory has been recovered from Late Neolithic, Copper Age, Bronze Age and Iron Age contexts, raising a great deal of interest among scholars (e.g. Camps 1960; Götze 1925; Harrison \& Gilman 1977; Jodin 1957; Leisner \& Leisner 1943; Poyato Holgado \& Hernando Grande 1988; Serra Ràfols 1925; Siret 1913). This interest has increased in the last two decades, as reflected by a very substantial body of literature (for the third and second millennia BCE, see e.g. Barciela González 2007; 2012; 2015; Cardoso \& Schuhmacher 2012; García Sanjuán et al. 2013; 2018b; Liesau Von Lettow-Vorbeck \& Moreno 2012; Liesau Von Lettow-Vorbeck \& Schuhmacher 2012; Liesau Von Lettow-Vorbeck et al. 2011; López Padilla 2012; López Padilla \& Hernández Pérez 2011; Luciañez-Triviño 2018; Luciañez-Triviño \& García Sanjuán 2016; Luciañez-Triviño et al. 2014; Morillo León et al. 2018; Nocete Calvo et al. 2013; Pascual Benito 2012; Pau et al. 2018; Schuhmacher 2012a,b; 2013; 2016; 2017; Schuhmacher \& Banerjee 2012; Schuhmacher et al. 2013a,b; Valera 2010; 2020; Valera et al. 2015; Vargas Jiménez et al. 2012). The literature on Iberian late prehistoric ivory is so vast that it greatly exceeds the scope of this paper-for a recent synthesis, see Luciañez-Triviño (2018). Our aim here is not to review the existing literature but to present a discussion of the roles played by ivory in the crafting of social and cultural idiosyncrasies (understood here as cultural practices or patterns peculiar to an individual or group of individuals, who used them to differentiate themselves from others, thus creating a sense of identity) during the Copper Age. In this period, the use of this raw material witnessed a true 'explosion', undoubtedly in connection with wider social and cultural phenomena. This discussion is based on a completely new analysis of the evidence obtained at Valencina de la Concepción (Seville, southern Spain), a site that lies at the forefront of current debates on Chalcolithic Iberia and which, as recent analyses have shown, offers not only the largest bulk of ivory for that period in Europe, but also a unique assemblage of artefacts, including finely crafted objects and unworked tusks (e.g. García Sanjuán et al. 2013; 2018b; Luciañez-Triviño 2018; Luciañez-Triviño \& García Sanjuán 2016; Luciañez-Triviño et al. 2014; Nocete Calvo et al. 2013; Schuhmacher et al. 2013a; Vargas Jiménez et al. 2012). The Valencina material provides an excellent basis to examine the social and cultural roles played by ivory among early complex societies, including types of objects, manufacturing processes, consumption, social significance, as well as conservation. As will be described below, our approach is based on a multi-disciplinary methodology that combines archaeology, experimentation and conservation-restoration (Luciañez-Triviño 2018).

\section{The evidence}

The Copper Age mega-site of Valencina de la Concepción-Castilleja de Guzmán (herein Valencina) is located about $6 \mathrm{~km}$ away from the historic centre of the modern city of Seville, in the north Aljarafe (Fig. 1). Activity at the site began $c$. 3200 cal. BCE and ended c. 2300 cal. BCE (García Sanjuan et al. 2018a). During the Chalcolithic, Valencina occupied a prominent place in an area of high strategic value for its proximity to several biotic and abiotic resources of great importance (García Sanjuán 2017; Vargas Jimenez et al. 2010).

Research at Valencina has made significant advances over the last decade. This has led to a more qualified assessment of processes associated with early social complexity, such as economic intensification, metallurgical production, craft specialization and social inequality (contributions to these debates in English include Costa Caramé et al. 2010; Inacio et al. 2011; García Sanjuán \& Murillo-Barroso 2013; Garcia Sanjuán et al. 2018a; Nocete Calvo et al. 2008; Rogerio-Candelera et al. 2013; Wheatley et al. 2012), based both on a stronger chronometric basis (García Sanjuán et al. 2018a) and a more precise understanding of exogenous raw materials, such as ivory, cinnabar, amber, gold, rock crystal and other lithic resources (e.g. García Sanjuán et al. 2016b; Hunt Ortiz \& Hurtado Pérez 2010; Hunt Ortiz et al. 2011; Luciañez-Triviño 2018; Luciañez-Triviño \& García Sanjuán 2016; Luciañez-Triviño et al. 2014; Morgado Rodríguez et al. 2016; Murillo-Barroso 2016a,b; Odriozola Lloret \& García Sanjuán 2013; Rogerio-Candelera et al. 2013; Schuhmacher et al. 2013a). For a synthesis of the history of the research at the site, see García Sanjuán (2013) and García Sanjuán et al. (2018a).

Our study includes all the ivory known to date from the site, that is, 384 artefacts, with an estimated total weight of $8.8 \mathrm{~kg}$, from 12 different features belonging to 8 of its sectors (Fig. 2). Of course, the state of preservation is a major issue for the identification of the raw material and its technological analysis. Significant differences of preservation have been found between different sectors, or even between objects from the same structure or assemblage. In general terms, the evidence is highly 


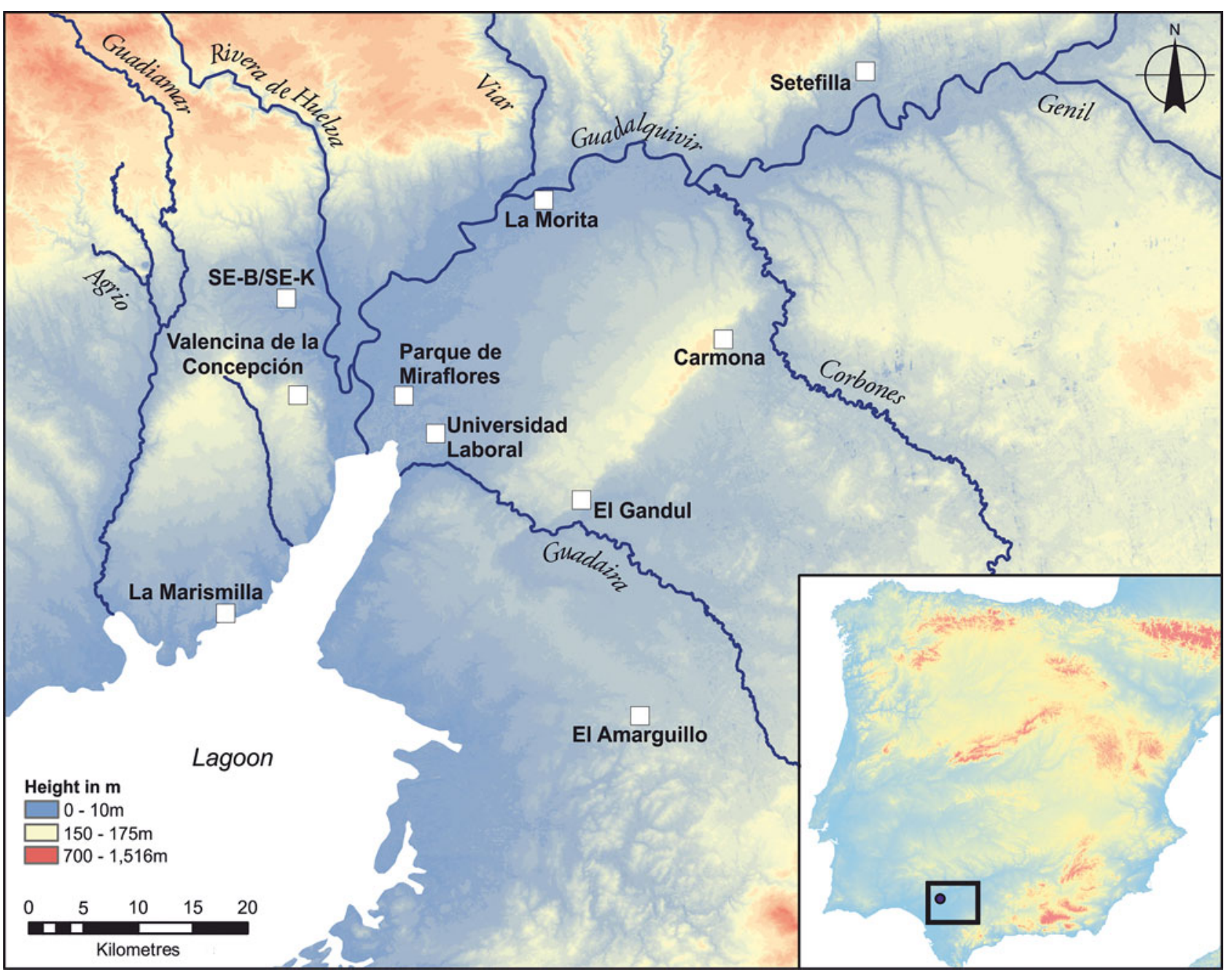

Figure 1. Location of Valencina de la Concepcion and other late prehistoric sites of the Guadalquivir basin showing the approximate coastline in the third millennium BC. (Source: García Sanjuán et al. 2018a: fig. 1. David Wheatley design from data courtesy of NASA EOSDIS LandProcesses Distributed Active Archive Center (LP DAAC), USGS/Earth Resources Observation and Science (EROS) Center, Sioux Falls, South Dakota.)

fragmentary, with few complete artefacts. The high degree of fragmentation has made it very difficult to obtain a 'Minimum Artefact Number'. For that reason, sometimes it has been necessary to count groups of fragments as a single item.

Tables 1 and 2 provide a synthesis of the contextual data of the features studied in this paper. Here we provide a short description of the sectors of the site to which they belong.

The Instituto de Enseñanza Secundaria (IES sector) is located roughly at the centre of the site. It was excavated in 2005-06, revealing over 150 negative features (sub-circular, circular, oval or polylobulated pits and shallow basins), mostly of prehistoric date (Vargas Jiménez et al. 2010). They seem to have served a variety of purposes, including metallurgical production, dwelling and burial (Nocete Calvo et al. 2013; Vargas Jiménez et al. 2010). Only one of those structures provided ivory items: Structure 402, an oval pit containing a single episode of filling.

The DIA Sector is located barely $50 \mathrm{~m}$ to the west of the IES, neighbouring the Matarrubilla Partial Plan Sector (hereafter PP-Matarrubilla) to the south. Excavations carried out in 2014 revealed multiple negative Copper Age structures (Ortega Gordillo 2015). The finds from this excavation are still under study, so the results are provisional. According to our study, however, two features contained ivory: Structures UC5 and UC63, neither of which has been radiocarbon dated, unfortunately.

The PP-Matarrubilla sector, located to the south of the DIA sector, was excavated in 2001, 2003 and 

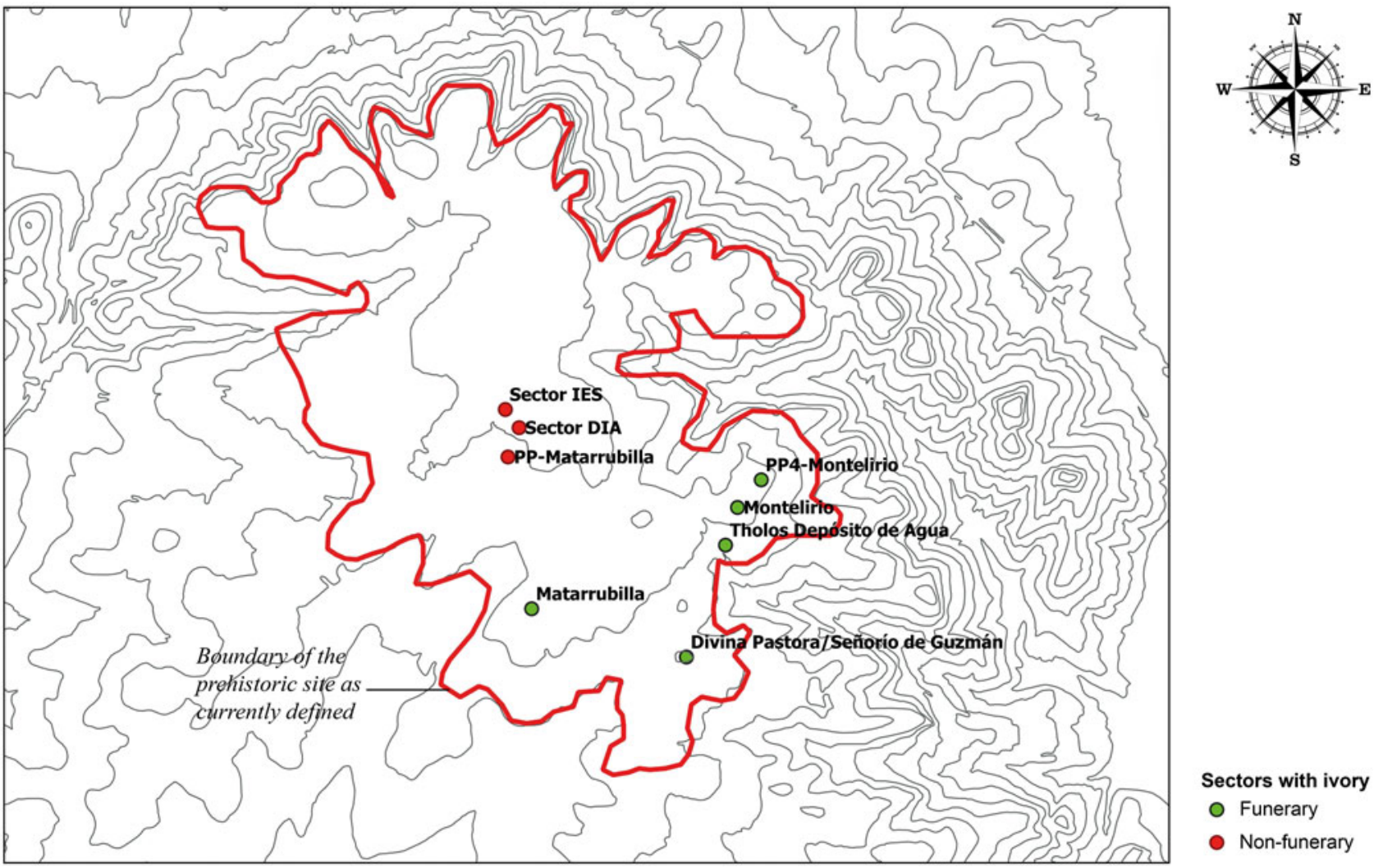

Sectors with ivory

○ Funerary

- Non-funerary

0

1

2

$3 \mathbf{~ k m}$

Figure 2. Sectors of Valencina with ivory.

2004, revealing a total of 198 prehistoric features (Nocete Calvo et al. 2008, 718). From this sector, we had access to only one artefact, the lower part of an anthropomorphic male figurine $(4.8 \mathrm{~cm}$ in length), about which unfortunately not much contextual information is available (Hurtado Pérez 2013, 313-14). The artefact is associated with the fill of structure \#50, which according to its excavators is defined by the presence of a living space (max. $3.70 \mathrm{~m}$ long and $2.40 \mathrm{~m}$ wide) and an attached well (max. $2.90 \times 2.70 \mathrm{~m}$ ). It has not been possible to confirm in which of the structures excavated in this intervention the piece appeared (Manuel Vargas Jiménez pers. comm., 2018).

The Montelirio tholos is located in the southeastern corner of the site, in the town of Castilleja de Guzmán. A major monograph (Fernández Flores et al. 2016) provides a detailed description of the architecture, finds and bio-archaeological record of this remarkable monument, dated to the twentyninth/twenty-eighth centuries BCE. A second monograph is currently in preparation (García Sanjuán et al. forthcoming). Montelirio is closely related both chronologically and socially to the neighbouring PP4-Montelirio sector, and particularly to tomb Structure $10.042-10.049$, located barely $200 \mathrm{~m}$ to the north, where the so-called 'Ivory Merchant' was found (García Sanjuán et al. 2013; 2018b): see description below. Montelirio is one of the largest Copper Age monuments in Iberia and has provided a suite of evidence that has allowed debate on the site to broaden-for a discussion, see García Sanjuán et al. (2017; 2018a,b,c).

The PP4-Montelirio sector is located in the southeastern part of the site, barely $100 \mathrm{~m}$ to the north of the Montelirio tholos. Excavations undertaken between 2007 and 2008 revealed 134 Copper Age features, both megalithic and non-megalithic, of which 61 contained human remains (Mora Molina et al. 2013). Still unpublished radiocarbon dates reveal that this sector was used over a relatively short period of time between 3000 and 2800 вСE. Despite the large number of structures, osseous artefacts are few in number $(n=46)$ and almost the 
Table 1. Summary of Valencina sectors under study.

\begin{tabular}{|c|c|c|c|c|c|c|}
\hline Sector & Structure & Type/Measurement & Material culture & Description of ivory finds & $\begin{array}{l}\text { Date } \\
\text { cal.BC }(2 \sigma)\end{array}$ & Reference \\
\hline IES Sector & 402 & $\begin{array}{l}\text { Negative, oval } \\
3.3 \times 1.96 \mathrm{~m}\end{array}$ & $\begin{array}{l}\text { Copper saw, ivory fragments, } \\
\text { pieces of bone industry } \\
\text { (fragments of pins and } \\
\text { production wastes), a fossil } \\
\text { seed, ceramic plates and } \\
\text { vessels, flint and rock crystal } \\
\text { fragments, ceramic crescents, } \\
\text { two beads made of Trivia } \\
\text { europaea }\end{array}$ & $\begin{array}{l}\text { Location: more or less concentrated } \\
\text { at the centre of the structure. } \\
\text { Description/Categories: Primary or } \\
\text { secondary blocks and blanks were } \\
\text { absent (these terms are explained in } \\
\text { 'Methodology'). Most of the items } \\
\text { are fragments with varying sizes } \\
\text { and shapes (fragments of slices and } \\
\text { some fragments of prismatic shape), } \\
\text { considered to be production waste } \\
\text { ( } \mathrm{n}=12 \text { ). An undetermined fragment } \\
\text { was interpreted as a possible dagger } \\
\text { hilt. } \\
\text { Ivory identification: five chips of } \\
\text { Asian elephant (Elephas maximus) }\end{array}$ & $2835-2580$ & $\begin{array}{l}\text { Vargas Jiménez et al. 2010; } \\
\text { 2012; } \\
\text { Nocete Calvo et al. 2013; } \\
\text { Luciañez-Triviño 2018; } \\
\text { García Sanjuán et al. 2018a }\end{array}$ \\
\hline DÍA Sector & UC5 & $\begin{array}{l}\text { Negative, oval } \\
\text { Max. surface diam. } \\
1.50 \mathrm{~m}\end{array}$ & $\begin{array}{l}\text { Semi-complete ceramic plate } \\
\text { (upside down and partially } \\
\text { covered by a large stone), } \\
\text { polished stone tool (chisel), } \\
\text { bone 'punch' fragment, flint } \\
\text { blade fragments, an } \\
\text { arrowhead, metal awl } \\
\text { fragments, abundant } \\
\text { malacofauna, abode with } \\
\text { vegetal imprints, some ivory } \\
\text { fragments }\end{array}$ & $\begin{array}{l}\text { Location: NA } \\
\text { Description/Categories:A quarter slice } \\
\text { of ivory and a flat square fragment. } \\
\text { All the evidence points to } \\
\text { production waste, although the } \\
\text { small square piece could be an } \\
\text { unfinished object. The largest ivory } \\
\text { artefact is the quarter slice ( } 16.18 \mathrm{~g}) \text {. } \\
\text { Early-stage products such as large } \\
\text { fragments of tusks (primary or } \\
\text { secondary blocks) or blanks are } \\
\text { absent. } \\
\text { Ivory identification: NA }\end{array}$ & NA & $\begin{array}{l}\text { Ortega Gordillo 2015; } \\
\text { Luciañez-Triviño } 2018\end{array}$ \\
\hline DÍA Sector & UC63 & $\begin{array}{l}\text { Negative, oval } \\
2.68 \times 2.15 \mathrm{~m}\end{array}$ & $\begin{array}{l}\text { Ceramic vessels, flint blade } \\
\text { fragments, other remains of } \\
\text { lithic industry, abundant } \\
\text { remains of fauna, } \\
\text { malacofauna, adobes, a boar } \\
\text { tooth fragment, one ivory } \\
\text { fragment }\end{array}$ & $\begin{array}{l}\text { Location: NA } \\
\text { Description/Categories: A flattened } \\
\text { fragment of possible ivory with } \\
\text { straight edges and abundant work } \\
\text { marks. All the evidence points to } \\
\text { production waste. Early-stage } \\
\text { products such as large fragments of } \\
\text { tusks (primary or secondary blocks) } \\
\text { or blanks are absent. } \\
\text { Ivory identification: NA }\end{array}$ & NA & $\begin{array}{l}\text { Ortega Gordillo 2015; } \\
\text { Luciañez-Triviño } 2018\end{array}$ \\
\hline PP-Matarrubilla & 50 & $\begin{array}{l}\text { Negative, irregular } \\
\text { shape }\end{array}$ & NA & NA & $\begin{array}{l}\text { Activity } \\
\text { started 2815- } \\
2495 \text { and } \\
\text { ended } 2570- \\
2425 \text { end }\end{array}$ & $\begin{array}{l}\text { Hurtado Pérez 2013; } \\
\text { Luciañez-Triviño } 2018\end{array}$ \\
\hline
\end{tabular}


Table 1. Continued

\begin{tabular}{|c|c|c|c|c|c|c|}
\hline Sector & Structure & Type/Measurement & Material culture & Description of ivory finds & $\begin{array}{l}\text { Date } \\
\text { cal.BC }(2 \sigma)\end{array}$ & Reference \\
\hline Montelirio tholos & Montelirio tholos & $\begin{array}{l}\text { Tholos, double } \\
\text { corridor and } \\
\text { chambers, walls of } \\
\text { slate slabs and } \\
\text { sun-dried clay } \\
\text { false-dome } \\
\text { Total length: } 43.7 \mathrm{~m} \\
\text { Passage: } 39 \mathrm{~m} \\
\text { LC max. Ø: } 4.75 \mathrm{~m} \\
\text { SC max. Ø: } 2.7 \mathrm{~m}\end{array}$ & $\begin{array}{l}\text { Large-sized 'almond-rim' } \\
\text { ceramic plates with fat } \\
\text { residues, bone artefacts } \\
\text { (possibly hair pins), knapped } \\
\text { lithic artefacts made of flint, } \\
\text { mylonite and rock crystal, } \\
\text { fragments of ostrich egg and } \\
\text { gold foil, garments crafted } \\
\text { with several tens of thousands } \\
\text { of perforated beads made of } \\
\text { marine shell, pendants made } \\
\text { of amber, ivory artefacts. }\end{array}$ & $\begin{array}{l}\text { Location: in the chambers } \\
\text { Description/Categories: LG: two } \\
\text { acorns with perforations, one } \\
\text { spiral-shaped object, two container } \\
\text { lids, } 10 \text { perforated discs, one or two } \\
\text { small D-section rings, one circular } \\
\text { mouths (for composite containers), } \\
\text { two combs with zoomorphic } \\
\text { decoration, a plaque in the shape of } \\
\text { a 'racquet' with a set of perforations } \\
\text { in circle, a possible decorated handle } \\
\text { of small size. SC: three combs } \\
\text { (geometric decoration), one or two } \\
\text { objects with zoomorphic decoration } \\
\text { (only the decorations are preserved: } \\
\text { possible suids), six acorns, one } \\
\text { decorated small plaque, one small } \\
\text { representation of a bird: possibly } \\
\text { pin head. Thousands of ivory } \\
\text { fragments, with no traces of work, } \\
\text { including a large tusk segment: } \\
\text { interpreted as resulting from a } \\
\text { single elephant tusk (or maybe two). } \\
\text { All the findings are finished objects } \\
\text { or fragments of them, but the } \\
\text { thousands of unworked fragments } \\
\text { have been included in the 'block' } \\
\text { category. } \\
\text { Ivory identification: Loxodonta } \\
\text { Africana africana (a comb and an } \\
\text { acorn from the SC); Elephas antiquus } \\
\text { (tusk segment from SC). }\end{array}$ & c. $2800-2700$ & $\begin{array}{l}\text { Altamirano García \& } \\
\text { Luciañez-Triviño 2016; } \\
\text { Luciañez-Triviño \& García } \\
\text { Sanjuán 2016; Pajuelo } \\
\text { Pando 2016; } \\
\text { Luciañez-Triviño } 2018\end{array}$ \\
\hline
\end{tabular}


Table 1. Continued

\begin{tabular}{|c|c|c|c|c|c|c|}
\hline Sector & Structure & Type/Measurement & Material culture & Description of ivory finds & $\begin{array}{l}\text { Date } \\
\text { cal.BC }(2 \sigma)\end{array}$ & Reference \\
\hline $\begin{array}{l}\text { PP4-Montelirio } \\
\text { Sector }\end{array}$ & $10.042-49$ & $\begin{array}{l}\text { Tholos, double } \\
\text { corridor and } \\
\text { chambers, walls of } \\
\text { slate slabs } \\
\text { Total length: } 20.1 \mathrm{~m} \\
\text { Passage: } 13 \mathrm{~m} \\
\begin{array}{l}10.042 \text { max. Ø: } 2.57 \\
\mathrm{~m}\end{array} \\
10.049 \text { max. Ø: } 2.1 \mathrm{~m}\end{array}$ & $\begin{array}{l}\text { UE664: an 'almond-rim' type } \\
\text { plate, } 21 \text { flint blades, a flint } \\
\text { dagger blade with, an amber } \\
\text { pommel, ivory objects. } \\
\text { Cinnabar was sprayed over } \\
\text { the body and objects } \\
\text { UE535: several ceramic plates, } \\
38 \text { whole flint blades and } \\
\text { other lithic tools, including a } \\
\text { flint arrowhead with very } \\
\text { long barbs, ivory objects, } \\
\text { discoid beads, an ostrich egg } \\
\text { (currently lost), a rock crystal } \\
\text { dagger blade }\end{array}$ & $\begin{array}{l}\text { Location:in the chambers } \\
\text { Description/Categories: 10.049-UE664 } \\
\text { an undecorated elephant tusk (laid } \\
\text { above individual's head), one vessel } \\
\text { with diamond decoration, one } \\
\text { vessel with diamond decoration and } \\
\text { two appendages, one rectangular } \\
\text { box, two combs (geometric deco). } \\
10.049-\text { UE535 a decorated elephant } \\
\text { tusk, one or two small D-section } \\
\text { rings, a composite dagger hilt, a } \\
\text { plaque with V-shaped perforations } \\
\text { in the reverse (sheath). } \\
\text { 10.042-UE648 one rectangular box, } \\
\text { one undetermined object. } \\
\text { All the findings are finished objects } \\
\text { or fragments of them, but the } \\
\text { unworked elephant tusk from } \\
\text { 10.049 has been included in the } \\
\text { 'block' category. } \\
\text { Ivory identification: Asian elephant } \\
\text { (Elephas maximus) (one cylindrical } \\
\text { vessel from UE664; a decorated } \\
\text { tusk, a decorated dagger hilt and a } \\
\text { carved plaque/sheath from UE535); } \\
\text { African elephant specimen } \\
\text { (Loxodonta Africana africana) (the } \\
\text { unworked tusk from UE664) }\end{array}$ & \multirow[t]{3}{*}{ c. $3000-2800$} & \multirow[t]{3}{*}{$\begin{array}{l}\text { Luciañez-Triviño 2018; } \\
\text { García Sanjuán et al. 2013, } \\
2019\end{array}$} \\
\hline $\begin{array}{l}\text { PP4-Montelirio } \\
\text { Sector }\end{array}$ & 10.076 & $\begin{array}{l}\text { Negative, oval } \\
1.69 \times 1.41 \mathrm{~m}\end{array}$ & $\begin{array}{l}\text { Globular ceramic vessel, one } \\
\text { ivory object }\end{array}$ & $\begin{array}{l}\text { Location: near individuals } \\
\text { Description/Categories: pointed } \\
\text { element, finish object }\end{array}$ & & \\
\hline $\begin{array}{l}\text { PP4-Montelirio } \\
\text { Sector }\end{array}$ & Decontextualized & NA & NA & NA & & \\
\hline
\end{tabular}


Table 1. Continued

\begin{tabular}{|c|c|c|c|c|c|c|}
\hline Sector & Structure & Type/Measurement & Material culture & Description of ivory finds & $\begin{array}{l}\text { Date } \\
\text { cal.BC }(2 \sigma)\end{array}$ & Reference \\
\hline Matarrubilla tholos & $\begin{array}{l}\text { Matarrubilla } \\
\text { tholos }\end{array}$ & $\begin{array}{l}\text { Tholos (corridor and } \\
\text { single burial } \\
\text { chamber), masonry } \\
\text { walls, stone } \\
\text { false-dome } \\
\text { Total length: } 37.7 \mathrm{~m} \\
\text { Passage: } 35.2 \mathrm{~m} \\
\text { Max. Ø: } 2.5 \mathrm{~m}\end{array}$ & $\begin{array}{l}\text { Large serpentine polished axe, } \\
\text { a hemispherical bowl of } \\
\text { marble limestone, red } \\
\text { pigments, a fragment of a } \\
\text { copper punch and several } \\
\text { hundred fragments of gold } \\
\text { foil. }\end{array}$ & $\begin{array}{l}\text { Location: central part of the corridor } \\
\text { Description/Categories: } 53 \\
\text { barrel-vault beads, seven } \\
\text { quadrangular beads with double } \\
\text { perforation, a possible handle, a } \\
\text { bracelet with herringbone } \\
\text { decoration, a fragment of a plaque } \\
\text { with perforations in circle, a } \\
\text { possible pendant, a small scone and } \\
\text { a tusk segment in a very poor state } \\
\text { of preservation. } \\
\text { All the findings are finished objects } \\
\text { or fragments of them. The tusk } \\
\text { segment has been included in the } \\
\text { 'block' category. } \\
\text { Ivory identification: Elephas maximus } \\
\text { (a pendant, four } \\
\text { adjacent-barrel-vaults beads and a } \\
\text { piece of 'raw' material; Elephas } \\
\text { antiquus (the tusk segment, two } \\
\text { square-beads, two } \\
\text { adjacent-barrel-vaults beads and a } \\
\text { perforated object, perhaps a } \\
\text { pendant). }\end{array}$ & $\begin{array}{l}\text { NA (Without } \\
\text { Beaker) }\end{array}$ & $\begin{array}{l}\text { Obermaier 1919; } \\
\text { Collantes de Terán 1969; } \\
\text { Schuhmacher 2012a } \\
\text { Luciañez-Triviño 2018; } \\
\text { García Sanjuán et al. 2018c }\end{array}$ \\
\hline $\begin{array}{l}\text { Depósito de Agua } \\
\text { tholos }\end{array}$ & $\begin{array}{l}\text { Depósito de Agua } \\
\text { tholos }\end{array}$ & $\begin{array}{l}\text { Tholos, double } \\
\text { corridor and } \\
\text { chambers, walls of } \\
\text { slate slabs and } \\
\text { sun-dried clay } \\
\text { false-dome }\end{array}$ & $\begin{array}{l}212 \text { discoidal beads, highly } \\
\text { fragmented and } \\
\text { unrecognizable ivory artefacts } \\
\text { and bone elements, an ochre } \\
\text { accumulation of more-or-less } \\
\text { circular shape }\end{array}$ & NA & $\begin{array}{l}\text { NA (Without } \\
\text { Beaker) }\end{array}$ & $\begin{array}{l}\text { Santana Falcón 1991; } \\
\text { Luciañez-Triviño } 2018\end{array}$ \\
\hline
\end{tabular}


Table 1. Continued

\begin{tabular}{|c|c|c|c|c|c|c|}
\hline Sector & Structure & Type/Measurement & Material culture & Description of ivory finds & $\begin{array}{l}\text { Date } \\
\text { cal.BC }(2 \sigma)\end{array}$ & Reference \\
\hline $\begin{array}{l}\text { Sector } \\
\text { 'Urbanización } \\
\text { Señorío de } \\
\text { Guzmán-Divina } \\
\text { Pastora' }\end{array}$ & Т 2 & $\begin{array}{l}\text { Tholos (corridor and } \\
\text { single burial } \\
\text { chamber), walls of } \\
\text { slate slabs } \\
\text { Passage: c. } 4 \mathrm{~m} \\
\text { Max. Ø: } 2 \mathrm{~m}\end{array}$ & $\begin{array}{l}\text { two globular vessels, two } \\
\text { lithic blades, a flint scraper, } \\
\text { bone tools, fragments of } \\
\text { decorated gold foils, ivory } \\
\text { artefact, red pigments }\end{array}$ & $\begin{array}{l}\text { Location: in the chamber? } \\
\text { Description/Categories: one flat } \\
\text { artefact with 'oculus' motif } \\
\text { (currently missing), one possible } \\
\text { cylindrical vessel. All are fragments } \\
\text { of finished objects, no evidence of } \\
\text { early-stage and intermediate } \\
\text { elements of the chaine opératoire were } \\
\text { found. }\end{array}$ & \multirow{3}{*}{ NA } & \multirow{3}{*}{$\begin{array}{l}\text { Arteaga Matute \& } \\
\text { Cruz-Auñón 2001; } \\
\text { López Aldana et al. 2015; } \\
\text { Schuhmacher 2012a; } \\
\text { García Sanjuán et al. 2013; } \\
\text { Murillo Barroso 2016b; } \\
\text { Luciañez-Triviño } 2018\end{array}$} \\
\hline $\begin{array}{l}\text { Sector } \\
\text { 'Urbanización } \\
\text { Señorío de } \\
\text { Guzmán-Divina } \\
\text { Pastora' }\end{array}$ & $\mathrm{T} 3$ & $\begin{array}{l}\text { Tholos (corridor and } \\
\text { single burial } \\
\text { chamber), walls of } \\
\text { slate slabs } \\
\text { Passage: } 1.3 \mathrm{~m} \text { (long } \\
\text { length) } \\
\text { Max. Ø: } 2 \mathrm{~m}\end{array}$ & $\begin{array}{l}\text { two possible globular vessels, } \\
\text { a vessel with straight and thin } \\
\text { walls, one lithic arrowhead, } \\
\text { one copper axe, two wild boar } \\
\text { teeth, other faunal remains, } \\
\text { red pigments and fragments } \\
\text { of ivory plaques }\end{array}$ & $\begin{array}{l}\text { Location: in the chamber? } \\
\text { Description/Categories: 'Ivory plaque } \\
\text { fragments' (currently missing) }\end{array}$ & & \\
\hline $\begin{array}{l}\text { Sector } \\
\text { 'Urbanización } \\
\text { Señorío de } \\
\text { Guzmán-Divina } \\
\text { Pastora' }\end{array}$ & $\mathrm{T} 5$ & $\begin{array}{l}\text { Tholos (corridor and } \\
\text { single burial } \\
\text { chamber), masonry } \\
\text { walls } \\
\text { Passage: }>4 \mathrm{~m} \\
\text { Max. Ø: } 3 \mathrm{~m}\end{array}$ & $\begin{array}{l}\text { two Bell-Beaker vessels (one } \\
\text { continental style and one } \\
\text { maritime style), two } \\
\text { hemispherical vessels, two } \\
\text { bowls, debris of lithic } \\
\text { knapping, } 600 \text { limestone } \\
\text { beads, some ivory fragments, } \\
\text { beads made from gold sheets, } \\
\text { one copper punch and slag }\end{array}$ & $\begin{array}{l}\text { Location: in the chamber? } \\
\text { Description/Categories: a possible } \\
\text { bracelet (currently missing), a } \\
\text { cylindrical object. All are fragments } \\
\text { of finished objects, no evidence of } \\
\text { early-stage and intermediate } \\
\text { elements of the chaine opératoire were } \\
\text { found. } \\
\text { Ivory identification: Elephas antiquus } \\
\text { (undetermined ivory fragments) }\end{array}$ & & \\
\hline
\end{tabular}


Table 2. Summary of the contextual data of the structures with ivory.

\begin{tabular}{|c|c|c|c|c|c|c|}
\hline Context & MNI, Humans & \multicolumn{2}{|c|}{ Ivory items } & $\begin{array}{l}\text { Weight } \\
\text { (g) }\end{array}$ & $\begin{array}{l}\text { Blocks or } \\
\text { secondary } \\
\text { blocks }(\mathrm{g}) \\
\end{array}$ & $\begin{array}{l}\text { Weight without } \\
\text { blocks or secondary } \\
\text { blocks (g) }\end{array}$ \\
\hline IES Sector, Struc. 402 & 0 & \multicolumn{2}{|l|}{16} & 35.5 & 0 & 35.5 \\
\hline DÍA Sector, Struc. UC5 & 0 & \multicolumn{2}{|l|}{2} & 17.43 & 0 & 17.43 \\
\hline DÍA Sector, Struc. UC63 & 0 & \multicolumn{2}{|l|}{1} & 1.97 & 0 & 1.97 \\
\hline PP-Matarrubilla, Struc. 50? & No data & \multicolumn{2}{|l|}{1} & 4.5 & 0 & 4.5 \\
\hline \multirow[b]{4}{*}{ Montelirio tholos } & \multirow{4}{*}{$\begin{array}{l}\text { LG: } 20 \\
12 \text { female } \\
3 \text { probably female } \\
5 \text { indeterminate } \\
\text { Prevalence of age range } \\
20-35 \text { years } \\
\text { SC: } 2 \\
1 \text { adult, possible female } \\
1 \text { adult, possible male }\end{array}$} & Total: & 108 & 5387.6 & 4851.3 & 536.3 \\
\hline & & LC & 49 & 697.3 & 263.61 & 433.69 \\
\hline & & SC & 58 & 4607.3 & 4504.1 & 103.2 \\
\hline & & $\begin{array}{l}\text { 2nd } \\
\text { Corridor }\end{array}$ & 1 & 83 & 83 & 0 \\
\hline \multirow{5}{*}{$\begin{array}{l}\text { PP4-Montelirio Sector, Struct. } \\
10.042-49\end{array}$} & \multirow{5}{*}{$\begin{array}{l}\text { 10.049: UE664: } 1 \\
\text { probable male, young, aged } \\
\text { between } 17 \text { and } 25 \text { years, } \\
\text { UE535: } 0\end{array}$} & Total: & 21 & 2565.32 & 1170.5 & 1394.82 \\
\hline & & $\mathrm{C} 49$ & 20 & 2532.82 & 1170.5 & 1362.32 \\
\hline & & UE664 & 12 & 1883.41 & 1170.5 & 712.91 \\
\hline & & UE535 & 8 & 649.41 & 0 & 649.41 \\
\hline & & $\mathrm{C} 42$ & 1 & 32.5 & 0 & 32.5 \\
\hline $\begin{array}{l}\text { PP4-Montelirio Sector, Struct. } \\
10.076\end{array}$ & $2^{*}$ (no data on sex and age) & \multicolumn{2}{|c|}{1} & 1.64 & 0 & 1.64 \\
\hline $\begin{array}{l}\text { PP4-Montelirio Sector, } \\
\text { decontextualized }\end{array}$ & - & \multicolumn{2}{|c|}{1} & 18.71 & & 18.71 \\
\hline Matarrubilla tholos & $\begin{array}{l}3 ? * \text { (without sex and age } \\
\text { data) }\end{array}$ & \multicolumn{2}{|l|}{81} & 646.27 & 326 & 320.27 \\
\hline Depósito de Agua tholos & No data & \multicolumn{2}{|l|}{3} & 21.77 & 0 & 21.77 \\
\hline $\begin{array}{l}\text { Sector 'Urbanización Señorío } \\
\text { de Guzmán-Divina Pastora', } \\
\text { T } 2\end{array}$ & $\begin{array}{l}3 \\
1 \text { adult female (22-28 years) } \\
1 \text { male (16-22 years) } \\
1 \text { indeterminate }\end{array}$ & \multicolumn{2}{|l|}{1} & 28.53 & 0 & 28.53 \\
\hline $\begin{array}{l}\text { Sector 'Urbanización Señorío } \\
\text { de Guzmán-Divina Pastora', } \\
\text { T } 3\end{array}$ & $\begin{array}{l}4 \\
1 \text { male adult ( } 24-30 \text { years) } \\
1 \text { female adult }(24-30 \text { years) } \\
1 \text { female pre-adult ( } 15-18 \\
\text { years) } \\
1 \text { infantile ( } 6-12 \text { years) }\end{array}$ & \multicolumn{2}{|l|}{1 (missing) } & - & - & - \\
\hline $\begin{array}{l}\text { Sector 'Urbanización Señorío } \\
\text { de Guzmán-Divina Pastora', } \\
\text { T } 5\end{array}$ & $\begin{array}{l}10 \\
1 \text { male adult ( } \pm 40 \text { years) } \\
1 \text { adult male }( \pm 35 \text { years) } \\
1 \text { male adult, aged } 24-30 \\
1 \text { female adult between } 24 \\
\text { and } 30 \text { years approx. } \\
3 \text { female adults (no age data) } \\
1 \text { pre-adult, aged } 13-17 \\
2 \text { children, between } 10 \text { and } \\
12 \text { years old }\end{array}$ & \multicolumn{2}{|l|}{5} & 113.33 & 0 & 113.33 \\
\hline
\end{tabular}

whole assemblage comes from Structure 10.04210.049. The architecture, material culture and skeletal remains found in this tomb have already been described in detail elsewhere (García Sanjuán et al.
2019). However, it is important to note that the single primary inhumation found in the lower level (UE664) of Structure 10.049 (a probable young male: Robles Carrasco \& Díaz-Zorita Bonilla 2013, 


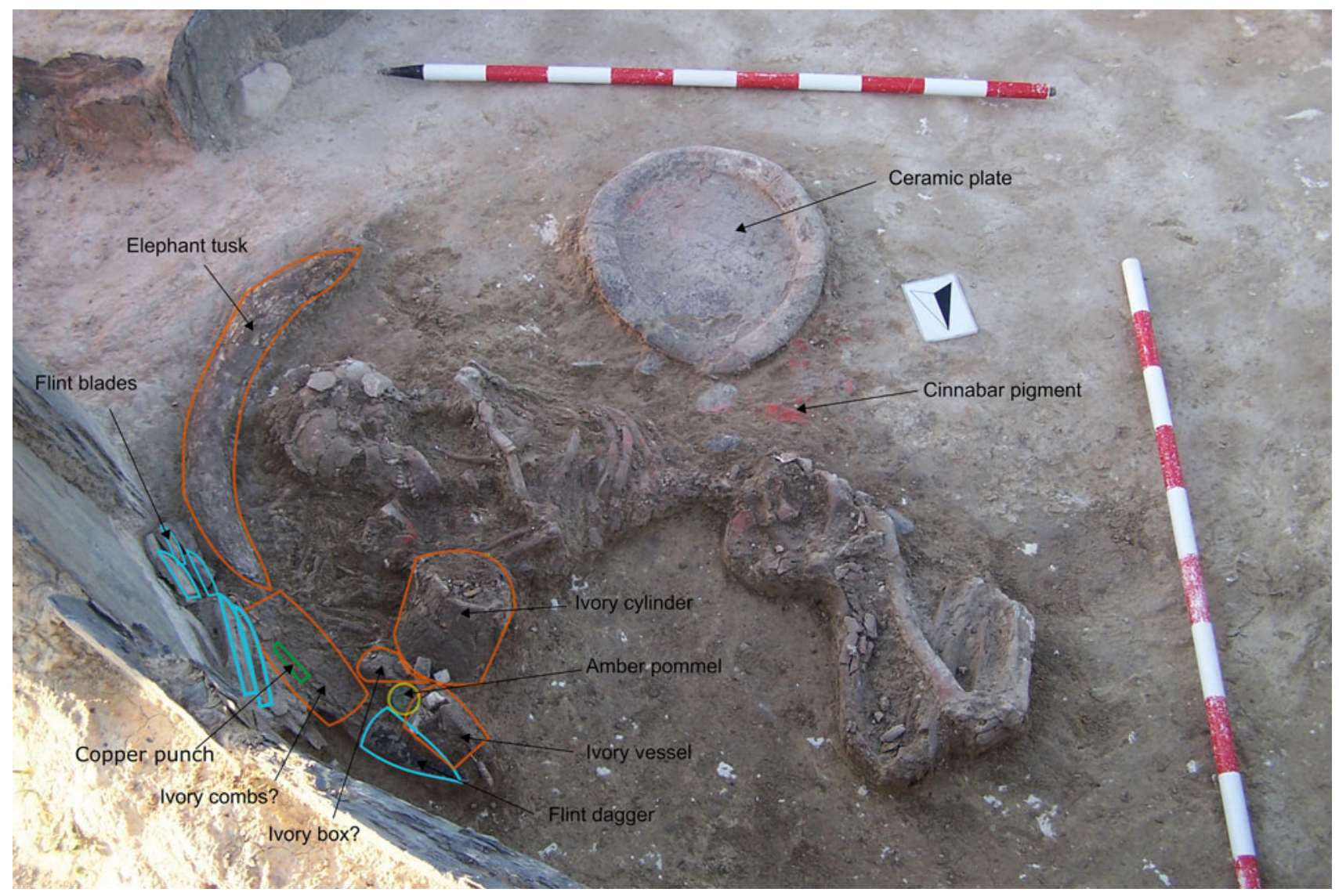

Figure 3. Human remains and grave goods of the buried adult individual found at the lower level (UE664) of the chamber of Structure 10.049. (Source: García Sanjuán et al. 2019.)

377) presented a remarkable set of grave goods (Fig. 3). Above this young man (UE535), another major assemblage of artefacts was laid, in this case without connection to human remains. This individual, nicknamed the 'Ivory Merchant', has been interpreted as a 'Big Man' or leader in the social history of Valencina (García Sanjuán et al. 2018b,c).

The Matarrubilla tholos is also located in the southern part of the site, approximately $1 \mathrm{~km}$ west of Montelirio and the PP4-Montelirio sector and 700 m west of Sector Urbanización Señorío de Guzmán/ Divina Pastora, described below. This major monument was discovered in 1917 and first excavated in 1918 (Obermaier 1919). A second excavation was carried out in 1955 (Collantes de Terán 1969). Unfortunately, not a single radiocarbon date has yet been obtained for it. The excavations undertaken in 1918 and 1955 yielded very few human remains, but an important suite of high-end material culture made of exotic raw materials.

The Depósito de Agua tholos was located in the area of Castilleja de Guzmán, just next to the
Montelirio tholos. A rescue excavation was carried out in June 1989, but the structure was wantonly destroyed (Santana Falcón 1991). No radiocarbon dates are available. The limited evidence available suggests this would have been a twochambered tholos similar to Montelirio, with earthen domes and painted slate slabs (Santana Falcón 1991, 448-9). Very limited material culture was collected.

The Urbanización Señorío de Guzmán-Divina Pastora sector is located $300-400 \mathrm{~m}$ to the south of the Depósito de Agua tholos, in the Castilleja de Guzmán municipality. Here, a rescue excavation undertaken in 1996 led to the discovery of 20 prehistoric features, mostly poorly preserved, of which only six were excavated. Two main types of prehistoric tombs were identified: those made from slate slabs and those from masonry (Arteaga Matute \& Cruz-Auñón 2001, 644). Of the six excavated structures, three, namely Tomb 2, Tomb 3 and Tomb 5, contained ivory. No radiocarbon dating is available for any of them. 


\section{Methodology}

Methodologically, our approach to the analysis of the Valencina ivory collections is based on the following steps: (I) identification of the raw material (proboscidean ivory versus other dentines and osseous materials); (II) conservation and restoration of the items in poor state of preservation in order to achieve a correct morphological identification; (III) classification of each artefact in a category of analysis; (IV) technological study under the microscope supported by a small experimental programme; and (V) contextual analysis.

The first fundamental step in the methodology was to discriminate the raw materials. For this purpose, a stereo microscope Nikon SMZ800 with two lenses $(0.5 \times$ and $2 \times)$ with magnifications up to $126 \times$, and a digital microscope (ShuttlePix P-400R) with a $20 \times$ optical lens, and magnification up to $400 \times$, both located at the Department of Prehistory and Archaeology of the University of Seville, were used. Observations under the microscope were then compared with the structural characteristics of different hard animal tissues according to the available bibliography (e.g. Abelová 2008; Choyke \& O'Connor 2013; Christensen 1999; Deschler-Erb 1998; Espinoza \& Mann 1991; 1993; 1999; Feldhamer et al. 1999; Haynes 1991; Kardong 1999; Krzyszkowska 1990; Locke 2008; MacGregor 1985; Rijkelijkhuizen 2008; Tolksdorf et al. 2015; Virág 2012) and with our own reference collection. In some cases, a fundamental part of the research was the conservation treatment and restoration of the remains, a laborious and time-consuming task which was, nevertheless, utterly necessary in order to reconstruct and identify some of the most sophisticated artefacts (Luciañez-Triviño et al. 2014).

Rather than focusing exclusively on the end products, that is, the finished objects, our research sought to understand all aspects involved in the ivory chaine opératoire, from the supply of the raw material and the manufacturing processes to end use, re-use and discard of the artefacts (i.e. their biography). Therefore, technical products such as raw material blocks, blanks, pre-forms (or roughouts) and debris (or production waste) were very much taken into account. In this way, the elements or categories of analysis used to classify the items in this collection include all these categories, according to general definitions set by Averbouh (2001). However, the specific categories for ivory technology were defined by us. Finished objects are the ultimate goal of the chaine opératoire and are generally the best-known products, mainly due to abundant typological studies. Finished objects have been categorized by integrating traditional terms into one of the two forms of tusk exploitation identified by us. To determine the forms of exploitation of the tusks, information has been collected on the debris, the shape of the finished objects and the characteristics of the raw material observable in them (which indicate the relative position of the object within the tusk).

The specifics of our research on ivory technology (including experimentation) go well beyond the scope of this paper and will be published separately. Briefly explained, to date, according to two modes of action on the raw material in relation to the longitudinal axis of the block (we understand the longitudinal axis as the distance that separates the tip of the tusk from the base), we have identified the transversal exploitation (perpendicular action to the longitudinal axis) and the longitudinal exploitation (parallel action to the longitudinal axis). Through transversal exploitation, blanks were obtained to manufacture the following types of objects: (T.I) Recipients and related artefacts: rectangular boxes, cylindrical mouths, curved/ oval base vessels, cornucopia-like objects and 'others' (such as ferrules or handle tops); (T.II) Perforated objects: rings and bracelets; and (T.III) Undetermined: dowel-like objects. Among the types of objects obtained through longitudinal exploitation are: (L.I) Recipients and related artefacts: handles and hilts; (L.II) Perforated objects: discs with central perforation, acorns, barrel-vault beads and double-perforated square beads; (L.III) Objects on longitudinal plaques: decorated or plain and perforated plaques, and lids; (L.IV) Barbed/Toothed elements: combs and ornamental combs; and (L.V) Figurines: human, animal, vegetal figurines or other shapes. A significant number of zoomorphic figurines were documented in the Montelirio tholos (Luciañez-Triviño \& García Sanjuán 2016, 257, fig. 9) that we believe were part of the decoration of other objects, such as combs. Today, they are free-standing due to fragmentation, but their technical characteristics indicate that they were obtained by longitudinal exploitation.

Valencina's ivory objects feature abundant and diverse decorations, which can be divided into decorations in low relief and openwork. The remains of painted decorations are neither evident nor abundant, and only one possible case of colour application was documented.

The decorations in low relief mainly represent motifs created through the combination of lines or 
A
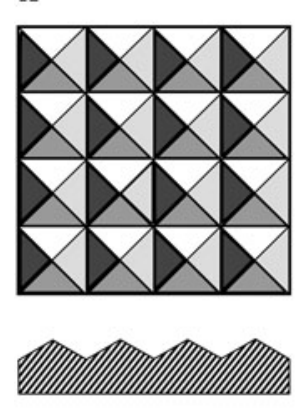

Figure 4. Schematic representation of low-relief patterns: $(A)$ diamond; $(B)$ mesh;(C) opposite zigzag;(D) rhomboid; (E) combination of decorations (from top to bottom) straight parallel lines, inverted triangles and herringbone pattern.
C

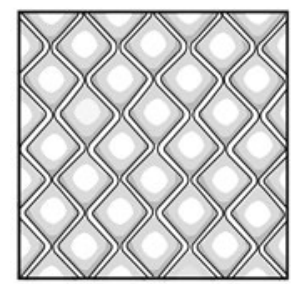

B

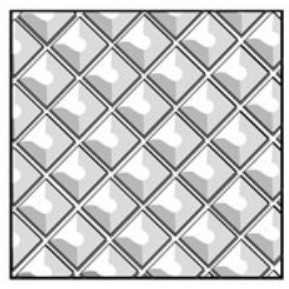

D

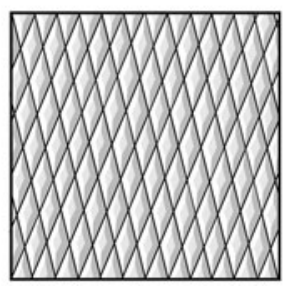

$\mathbf{E}$

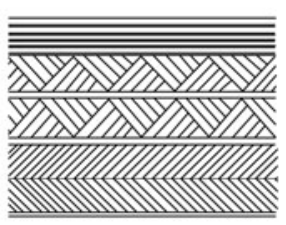

geometric forms and they often appear in bands (Fig. 4). The following patterns have been identified:

(I) Diamond: made by deep straight grooves, generally with an open $\mathrm{V}$ section, which, when crossed, generate square or almost square relief spaces in the form of four-sided pyramids, or truncated pyramids (flattened cusps). They generally make up an all-covering decoration, which affects all or a large part of the surface. Thus, it can be found on the entire outer face of objects such as vessels or in bands in composite decorations.

(II) Mesh: motif with appearance of a relief-like mesh, leaving the intermediate spaces slightly bulky. They generally make up an extensive and covering decoration.

(III) Opposed zigzag: made by continuous zigzag lines in relief, which adjacently face their vertices. They generally cover the whole surface of the object.

(IV) Rhomboid motif: made from grooves of generally V-shaped section of little depth that intersect with each other leaving rhomboidal spaces in relief. It is used as a covering decoration and for the elaboration of the acorn's cupule.

(V) Inverted triangles: several parallel lines that change their orientation with regular frequency, thus creating triangles.

(VI) Herringbone pattern: two bands of parallel lines in reverse direction that form a pattern similar to a cereal ear.
(VII) Straight parallel lines: in relief made with incisions or grooves.

(VIII) Convex protrusions ('mamelones').

(IX) Cord: relief pattern with a concave profile that protrudes from the surface up to $c .3$ $\mathrm{mm}$, and can be rectilinear or curved, adapting to the contour of the piece.

(X) Adjacent barrel vaults: motif giving appearance to the surface of attached tubes (Fig. 5).

The openwork decoration has only been identified in the Montelirio combs and the motifs represented are exclusively zoomorphic and 'opposing canes'. The identified zoomorphic motifs appear to represent quadrupeds, possibly suids (pigs or wild boars), but not all are easily recognizable (Luciañez-Triviño \& García Sanjuán 2016). Only one case represents a bird. The so-called 'opposing canes' are a main motif in the openwork decoration of the Montelirio combs. It is based on a series of elongated 'bodies' that curve towards the centre of the piece and are topped by spheres. They appear opposite to each other, in variable numbers (odd or even) (Fig. 6).

\section{Results}

Scales of consumption

With a recorded $8.8 \mathrm{~kg}$, Valencina has yielded what to date is by far the largest ivory collection in Chalcolithic Iberia (García Sanjuán et al. 2018b; Luciañez-Triviño 2018) and one of the largest (if not the largest) for western Europe. With few exceptions, the main assemblages of this raw material are 

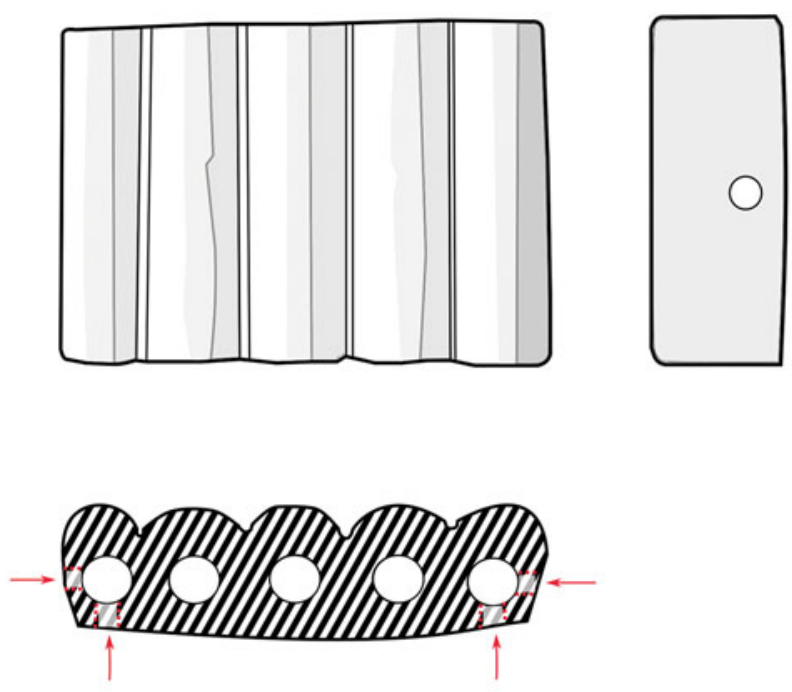

$3 \mathrm{~cm}$

Figure 5. Schematic representation of a barrel-vault bead and adjacent barrel vaults decoration.

associated with major megalithic monuments such as Montelirio, Matarrubilla and Structure 10.04210.049. In the structures in which ivory has been found, ivory is the most widely used osseous raw material, representing 65 per cent of the worked osseous industry, followed by animal bone ( 21 per cent) (Fig. 7).

The tomb with the greatest total number of objects (complete artefacts, fragments and groups of fragments) is Montelirio with 105 items, followed by Matarrubilla with 81 and Structure 10.04210.049 with 21 (Table 2; Fig. 8). Considering the total weight instead of counting artefacts changes the picture slightly, but Montelirio continues to have the largest collection with $5.387 \mathrm{~kg}$ (Small Chamber $=4.607 \mathrm{~kg}$; Large Chamber $=0.7 \mathrm{~kg}$ ), followed by Structure $10.042-10.049$ with $2.565 \mathrm{~kg}$ in total $(10.049$, base level $=1.883 \mathrm{~kg} ; 10.049$, upper level $=0.649 \mathrm{~kg} ; \quad 10.042=0.032 \mathrm{~kg}), \quad$ and by Matarrubilla with $0.646 \mathrm{~kg}$ (Luciañez-Triviño \& García Sanjuán 2016). We have discussed an interpretation of these numerical data elsewhere (García Sanjuán et al. 2018b). The disparity between the object count and the total weight responds to the presence of heavy segments of elephant tusks. When these are excluded, the weight results read like this: Montelirio $=0.536 \mathrm{~kg}$; Structure 10.042 $10.049=1394 \mathrm{~kg}$; Matarrubilla $=0.320 \mathrm{~kg}$. This is consistent with the size of the objects deposited in each grave. The sizes of the artefacts from Structure 10.042-10.049 are much larger: e.g. the plaque/ sheath is $c .30 \mathrm{~cm}$ long in its current state, and the carved tusk measures about $40 \mathrm{~cm}$. At Montelirio, the largest items are the possible container lids (maximum length between 11.7 and $12 \mathrm{~cm}$ ) and a comb measuring $c .12 \mathrm{~cm}$. At Matarrubilla, the assemblage contains basically a high number of beads (the largest is only $2.6 \mathrm{~cm}$ long), and the largest item (a plaque with perforations) measures only $6 \mathrm{~cm}$ in its current state. Considering the weight of the artefacts (excluding blocks), Structure 10.042-10.049 contains the largest amount, precisely due to the large size of the objects (Fig. 9). But in terms of total weight, Montelirio has twice as much ivory as 10.04210.049 , with 60 per cent of the total ivory of the site (Fig. 10). Therefore, 90 per cent of the ivory from Valencina is concentrated in two large monuments, especially in Montelirio.

In general, the raw data on the total weight and number of ivory objects are scarce and difficult to obtain due to fragmentary publication. This limits the quantitative assessment and comparison of the Valencina collection at an Iberian and international level. Only in a partial and indicative way can we compare the Valencina data with the site of Perdigões in Portugal, where 1886 ivory items were recorded $(3.4 \mathrm{~kg})$. Tomb 2 stands out with $1.8 \mathrm{~kg}$, while Fossa 40 yielded $1 \mathrm{~kg}$ of ivory (Valera 2020, 139 and table 3). At a Mediterranean level, both in Greece and the Levant, ivory was abundant from the Bronze Age to the Hellenistic period (Fitton 1992). Unfortunately, apart from some exceptions, no quantitative estimates like those handled here are available. We can cite a context interpreted as a workshop in Knossos in which over $1 \mathrm{~kg}$ of small chips were recovered (Krzyszkowska 1992, 31, n. 15). By comparison, in Valencina only 15 fragments of debris (totalling only $50 \mathrm{~g}$ ) have been found. The differences between the amount of chips and debris at both sites suggests that interpretations concerning the existence of workshops and the probable scales of production in Iberia must be made carefully, especially regarding the interpretation of the local production of objects, as no straightforward or simple correlations exist between the former and the latter.

\section{Morphologies and designs}

As we have already mentioned, the degree of fragmentation across all of the assemblages is very high, so that the number of objects is probably overrepresented. Nevertheless, through meticulous study 


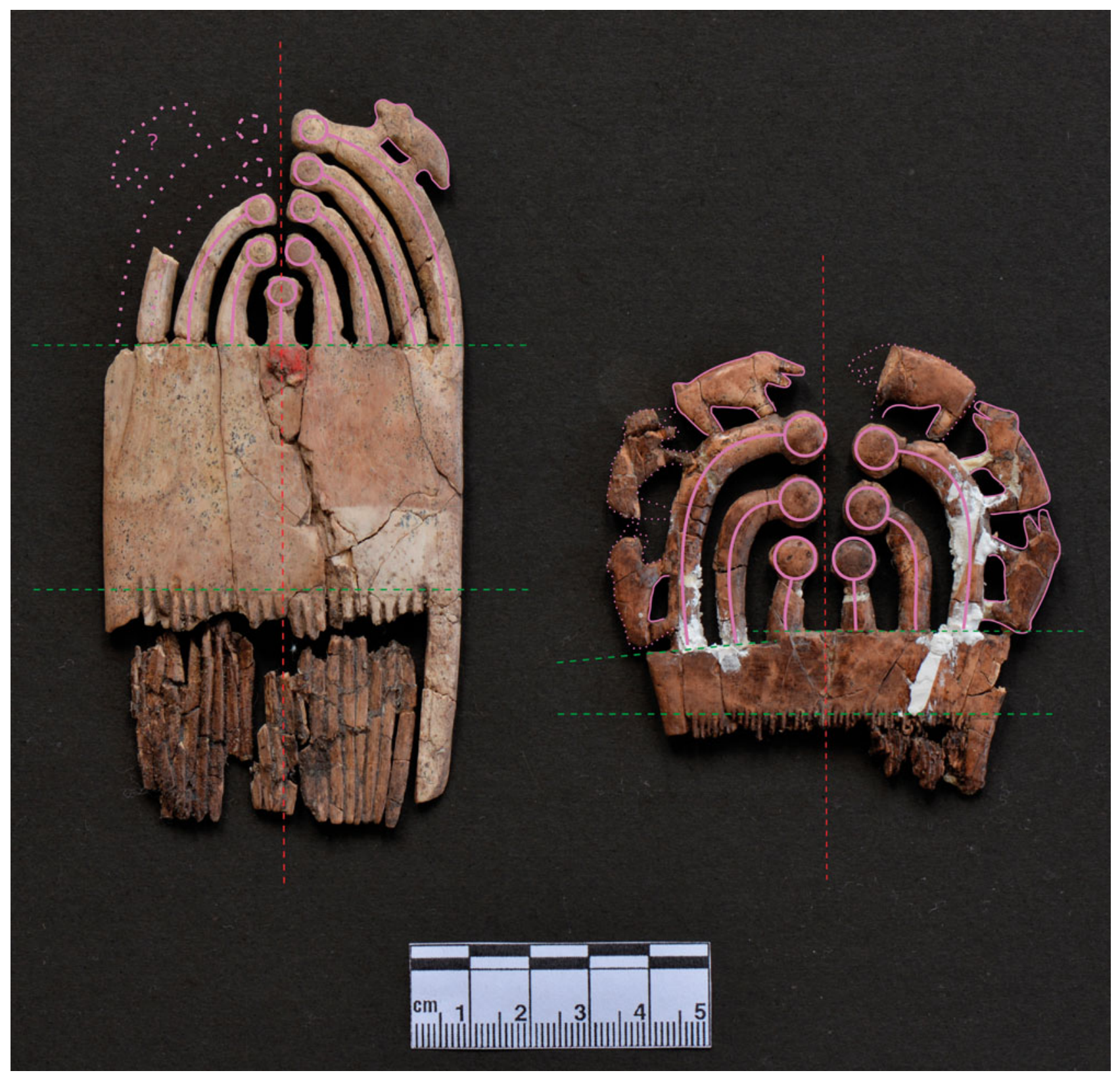

Figure 6. Montelirio combs with openwork decoration.

under the microscope, a full inventory of end products was made.

At IES, Structure 402, most of the recorded items are debris $(n=12)$ of prismatic shapes or fragments of thin slices. Evidence of finished objects (n $=4)$ is scarce and difficult to interpret: an undetermined 'recipient/receiver' (T.I, perhaps part of a handle, like a ferrule or top), a plaque with two perforations (L.III), and two bolt-like T-shaped objects (T.III). There is no evidence of decoration on any of the pieces. Structure 50 of PP-Matarrubilla delivered the only anthropomorphic figurine of ivory found to date in Valencina. As already explained, it is the lower part of a male body (L.V) (Hurtado Pérez 2013, 313-14, figs 2-3 \& 3).

For the Small Chamber of Montelirio, the morphology of 14 objects was established with certainty: one elongated handle with circular section and insertion in the axis through a blind hole (L.I); one or two objects decorated with zoomorphic figurines (combs or another type of object with openwork decoration, L.IV); decoration in the shape of a bird of 


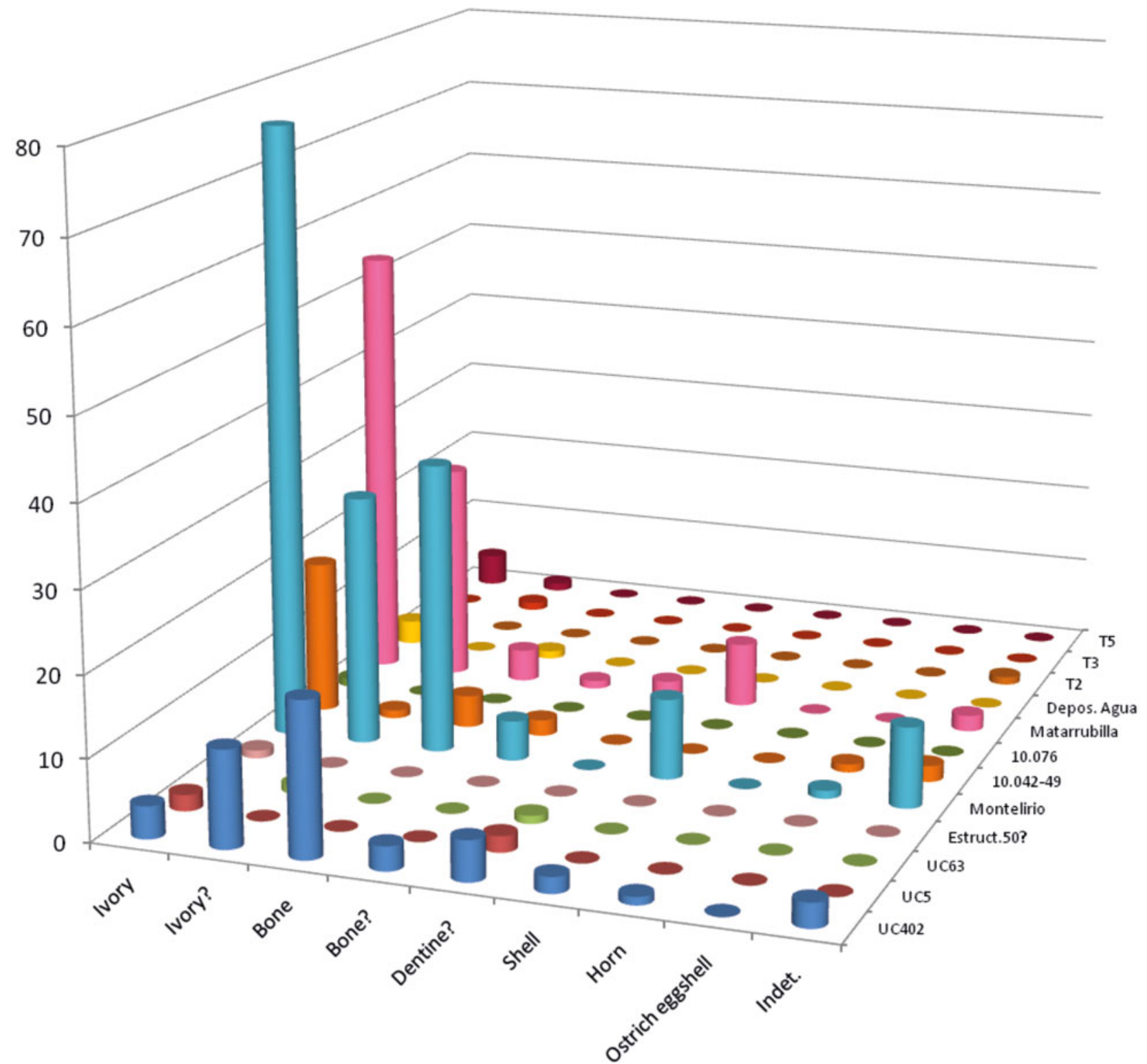

\begin{tabular}{|c|c|c|c|c|c|}
\hline UC402 & चUC5 & UC63 & Estruct. $50 ?$ & Montelirio & $=10.042-49$ \\
\hline$=10.076$ & Matarrubilla & Depos. Agua & $=\mathrm{T} 2$ & $=\mathrm{T3}$ & a T5 \\
\hline
\end{tabular}

Figure 7. Osseous raw materials by structure.

a possible pin (L.V); a small decorated plaque (L.III); six acorns (L.II); and three possible combs (L.IV). These last combs show different decorations: one of them shows the same decoration on both sides (herringbone pattern), while the other specimen has different decoration on each side (mesh patterning on one side and opposite zigzag motif on the other). To this we must add the thousands of fragments catalogued as raw material, which indicate the deposition of one or two tusks. In the Large Chamber of Montelirio, 23 objects were identified: two acorns with perforations (L.II); one spiral-shaped object (L.V); two semi-circular lids (L.III); 10 perforated discs (L.II); one or two small D-section rings (T.II); one mouth of a composite object (cylindrical form with external decoration of straight parallel lines) (T.I); another possible container's mouth without decoration (T.I); two combs with zoomorphic 


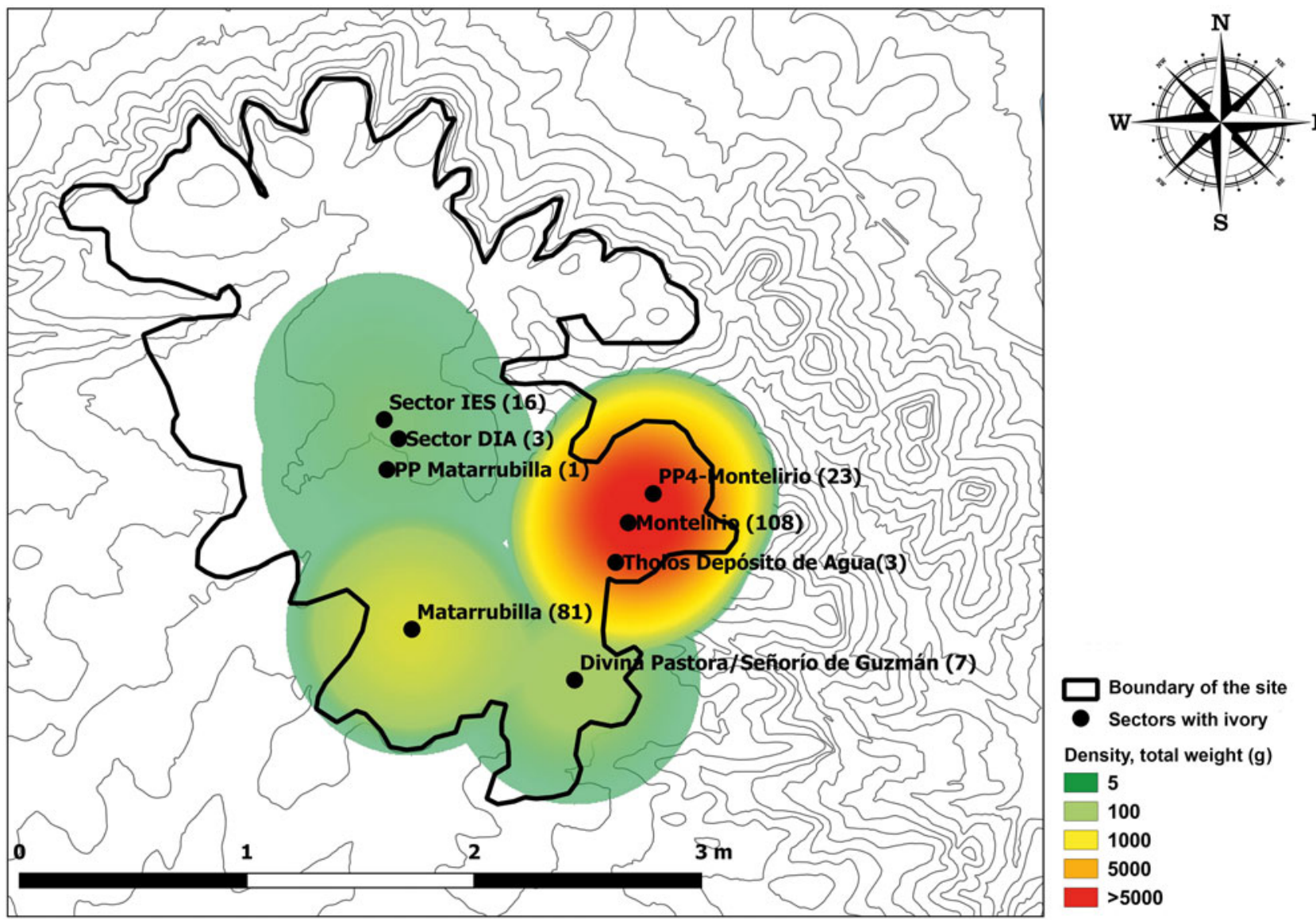

Figure 8. Density map based on the total weight of the finds.

and 'opposing canes' decoration (L.IV); a racquet-like plaque with a set of perforations in a circle (undeterminedobject, without parallels, L.III); and a possible small handle (L.I).

In Structure 10.049 of the PP4-Montelirio sector, six objects were securely identified for the upper depositional level: a diamond-decorated elephant tusk (T.I); one or two small D-section rings (T.II); a composite dagger hilt with mesh decoration (L.I); a decorated plaque with mesh pattern on the obverse and $\mathrm{V}$ perforations on the reverse (possible sheath) (L.III); and a small plaque with diamond decoration (L.III). In the lower level of Structure 10.049, in direct association with the 'Ivory Merchant', six objects were identified: one oval-based vessel with diamond pattern decoration (T.I); an oval-based vessel with diamond pattern decoration and two appendages (Fig. 11) (T.I); fragments of a cylindrical object (T.I); one rectangular box with diamond-pattern decoration (T.I); and two decorated combs (L.IV). One of these combs has herringbone pattern on one side (the other is poorly preserved), while the other comb has mesh pattern decoration on both sides. In addition, as mentioned above, one unworked tusk divided into three segments was deposited. In Structure 10.042 only one small rectangular box with diamondpattern decoration (T.I) was identified (Fig. 12).

For the Matarrubilla tholos we have identified 65 objects: 53 adjacent-barrel-vaults beads (L.II); seven double-perforated square beads (L.II); one small handle (T.I); a bracelet with herringbone pattern decoration (T.II); a fragment of a plaque with perforations in a circle (L.III); a possible pendant (L.III); and a small appliqué with a perforated tongue for its fastening (indet.). In addition, a segment of tusk (secondary block) was found.

For Urbanización Señorío de Guzmán/Divina Pastora, we have recognized a cylindrical object ( $T$. I) for Tomb 2 and another possible cylindrical object (T.I) for Tomb 5. Some materials from Señorío de Guzmán/Divina Pastora are missing and are known only from bibliographic references. According to these, T3 yielded ivory plaques and T5 a bracelet (Arteaga Matute \& Cruz-Auñón 2001). The form and some technological marks observed on the surface of the material of Depósito de Agua 


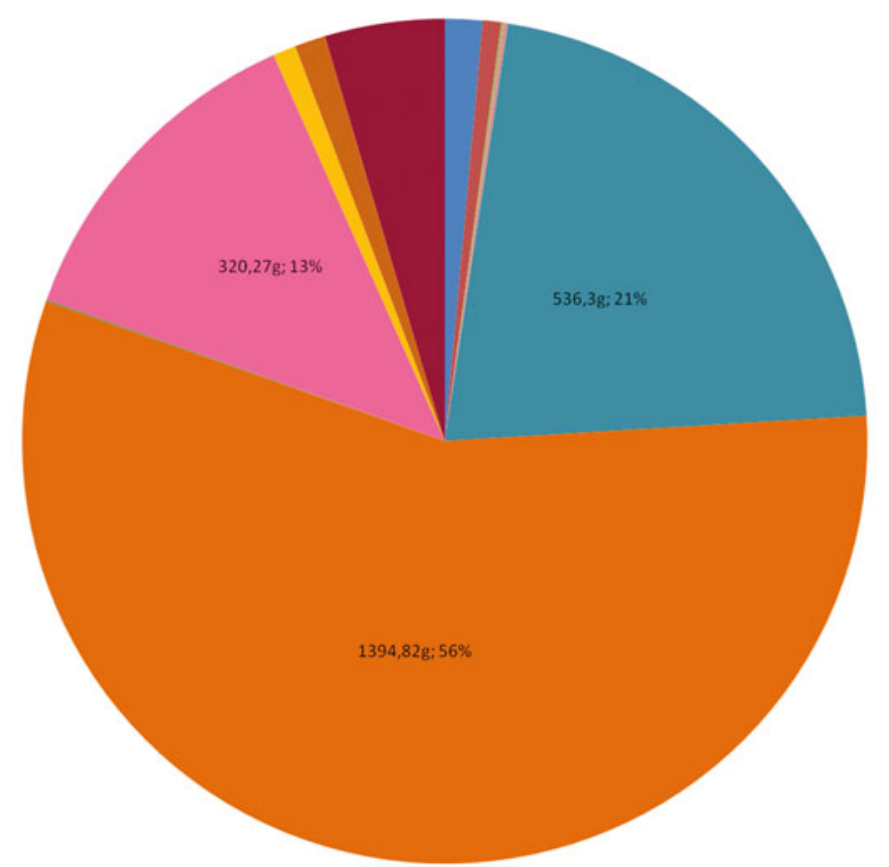

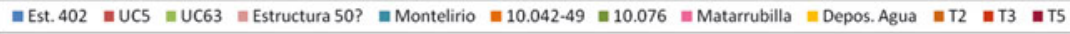

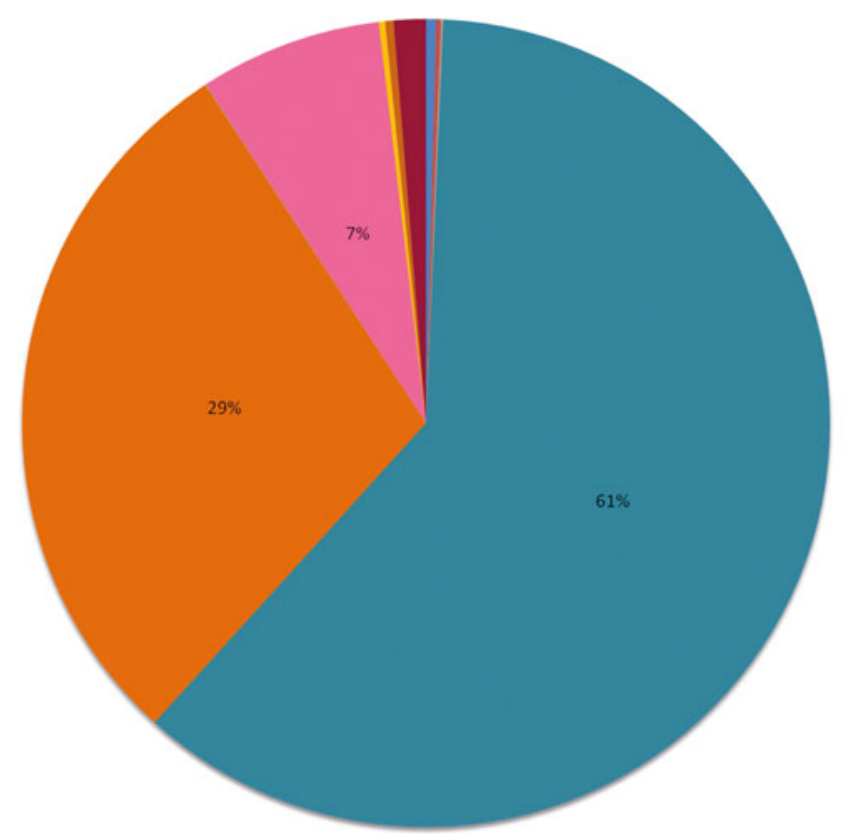

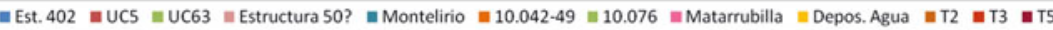

Figure 9. Distribution of ivory in Valencina according to the weight $(g)$ of objects in each context.

Figure 10. Distribution of ivory in Valencina according to the total weight in each structure. tholos point to the deposition of objects, but unfortunately no specific morphologies have been recognized.

These data reveal six important points:

(I) 75 per cent $(n=178)$ of the ivories studied here are finished objects or fragments of them;

(II) in the site there are to date only 15 items of production waste;
(III) in the pits interpreted in connection with production contexts, no blanks or blocks were found, which, however, did appear in some of the tombs: one or two in the Small Chamber of Montelirio, one in Structure 10.049 (lower level) and a segment in Matarrubilla (corridor); 

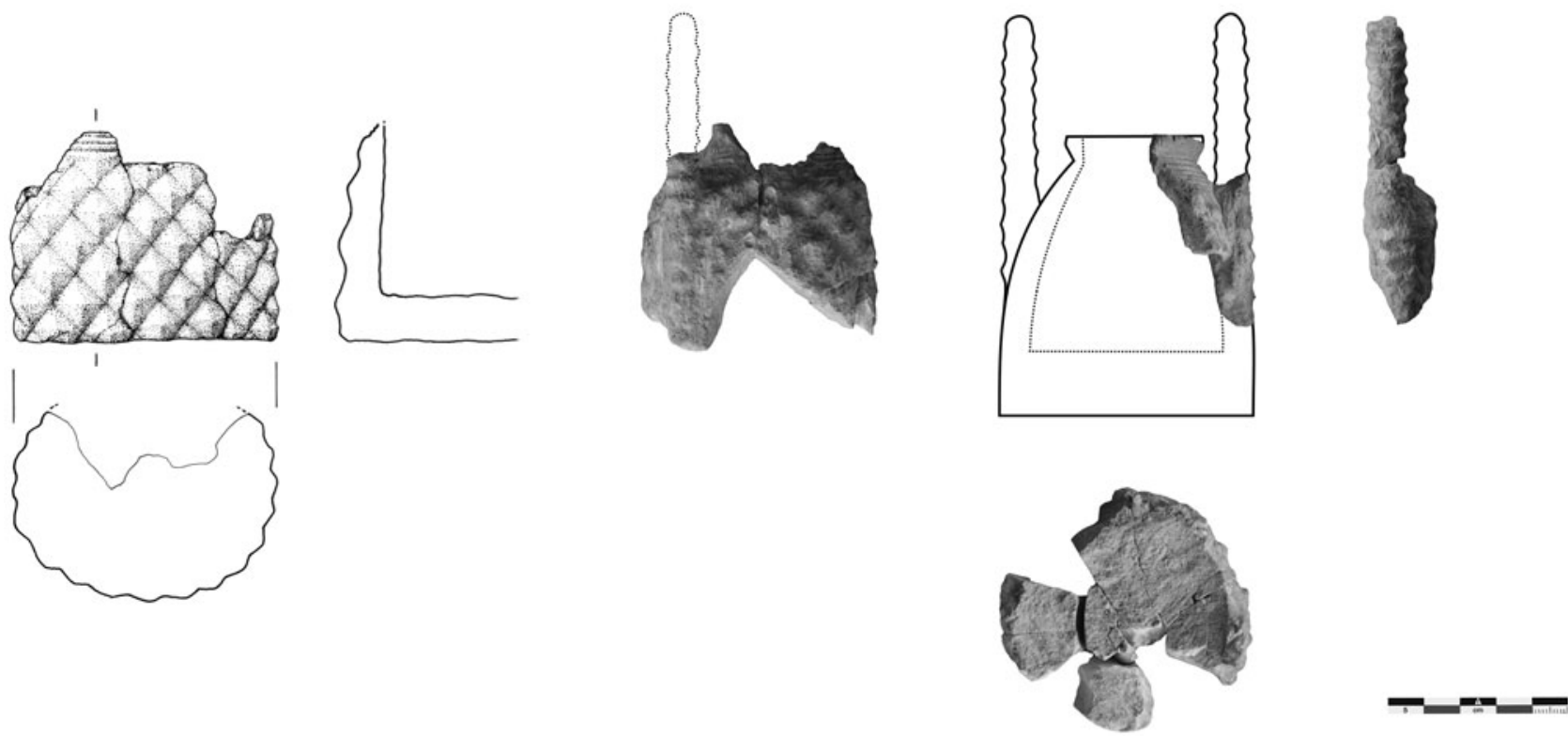

Figure 11. (Left) Oval-based vessel with diamond decoration and (right) oval-based vessel with diamond decoration and two appendages (PP4 Sector, Structure 10.049, UE664).

(IV) there is a pervasive technical uniformity across the entire Valencina assemblage, with 72 per cent of the objects obtained by longitudinal exploitation;

(V) most objects are unique;

(VI) each tomb has a singular assemblage.

\section{Contexts of deposition}

As mentioned above, the vast majority of Valencina's ivory was found inside megalithic tombs, either large or medium-sized. These are Montelirio, structures 10.042-10.049 and 10.076 in the PP4-Montelirio sector, Matarrubilla, Depósito de Agua and tombs T2, T3 and T5 in the Divina Pastora/Señorío de Guzmán sector. It is important to note that all of them are tholos-type megaliths. Four other structures where ivory was found, basically simple pits, appear to have been related to activities other than burial, possibly linked to craft and production tasks: these are UC402 from IES, UC5 and UC63 from DIA and Structure 50 from PP-Matarrubilla. However, the amount of ivory found in these non-burial features is tiny: $59.5 \mathrm{~g}$. Altogether, Valencina hoards $8.8 \mathrm{~kg}$ of ivory.

It is therefore verified that in Valencina ivory was, in fact, almost exclusively deposited in funerary contexts, specifically in tholos-type monuments. In structures related to activities other than ritual and/or burial (such as production, storage, dwelling), ivory artefacts do not show any specific pattern of deposition. By contrast, in those tholoi, ivory always was found in the chambers, with two exceptions: Matarrubilla and Depósito de Agua. In the case of Depósito de Agua, the discovery of the ivory fragments in the corridor may be due to the destruction of the structure, as occurs with the few remains found in the corridor between the chambers of the Montelirio tholos. However, in Matarrubilla the deposition of the ivory material in the corridor is clear. No ivories were found in the Matarrubilla chamber. This unusual location suggests that the Matarrubilla ivories were deposited at a later stage in the biography of the monument. The fact that ivory is found primarily in the chambers of these great monuments may have to do with their specific relationship with the people buried in them (Montelirio and Structure 10.049) ${ }^{1}$ or with the role played by the chambers within the rituals staged inside the monuments-see, for example, the key role played by the stela in the Large Chamber of Montelirio.

The ivories generally appear in connection with collective burials (Table 2), with two exceptions: the 


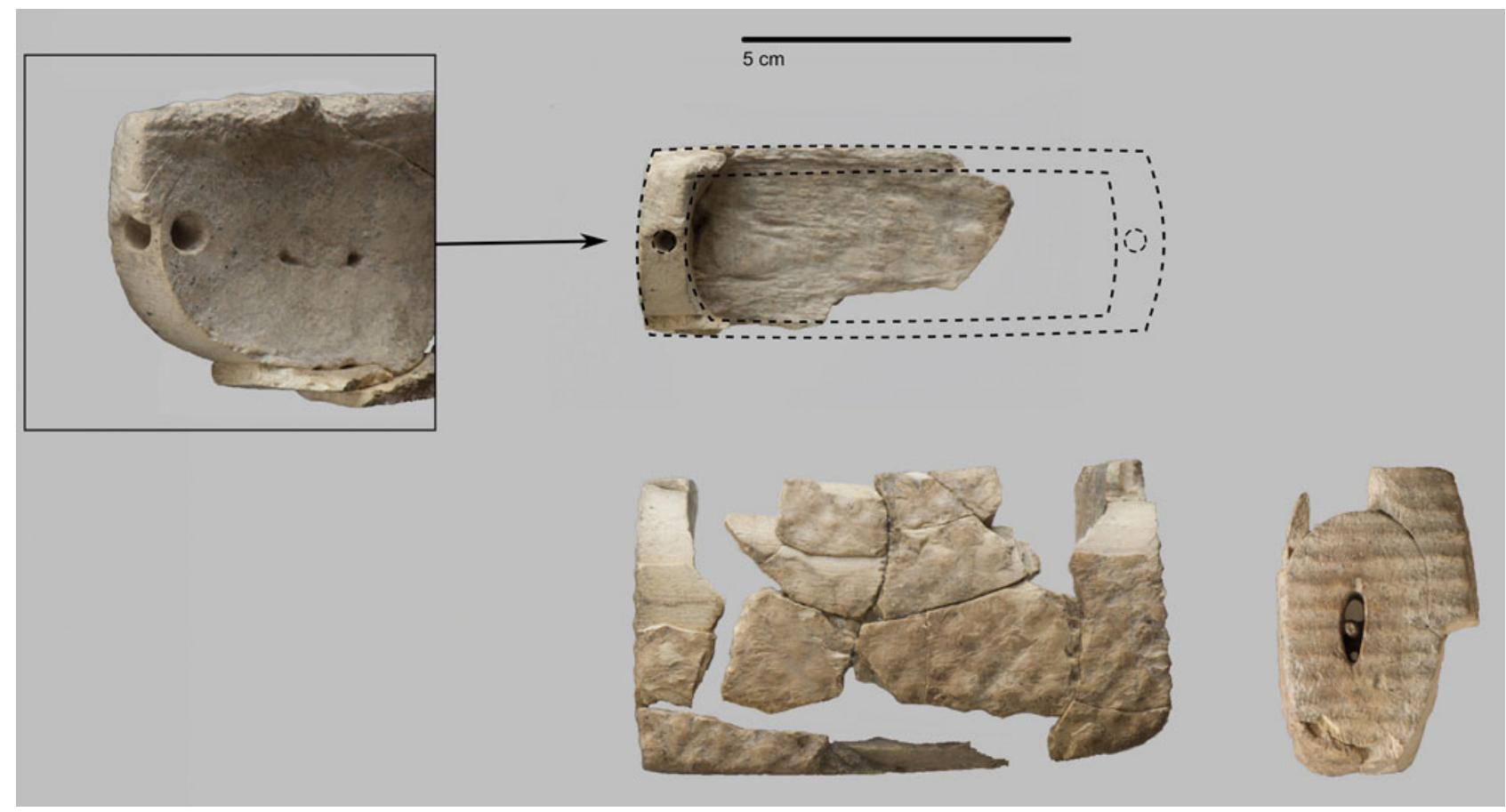

Figure 12. Small rectangular box (PP4 Sector, Structure 10.042).

lower level in Structure 10.049, where the 'Ivory Merchant' was found, and the upper level of this very same tomb, where no human remains were found. Thus, only in the case of this young male could we speak of an individualized set of grave goods, given that all the ivory objects appeared accumulated in front of his arms, and the tusk was placed 'framing' his head (see Figure 3). Although badly disturbed by later activity, the bones of at least two individuals were identified in the SC of Montelirio, a chamber that shows a subtle connection with the 'Ivory Merchant' buried in Structure 10.049: as mentioned above, one or two elephant tusks and several comb fragments with geometric decoration were deposited in the SC (the latter with herringbone, mesh and opposite zigzag patterns of decoration), as is the case with the grave goods of the 'Ivory Merchant'. Conversely, all the ivory artefacts of the Large Chamber appeared around the clay stela (Fig. 13) and only a single piece was related beyond doubt to one of the 20 individuals buried there: an acorn-shaped pendant found under the left shoulderblade of individual UE343 (female, aged 24-32 years) (Fig. 14) (Díaz-Guardamino Uribe et al. 2016; Luciañez-Triviño \& García Sanjuán 2016, 255). It is not possible to rule out that this acorn was a pendant used as part of an elaborate costume worn by this woman, and that it fell down with the decomposition of the body, being later located behind her back.
Therefore, in the LC of Montelirio it seems that the ivories form rather an offering to the stela, or a collective set of grave goods, since they were not arranged in such a way that they could be associated with specific individuals. In addition, in Montelirio some ivory artefacts are pieces or parts of other elements. Two large containers were placed behind the stela (Bueno Ramírez et al. 2016; Fernández Flores \& García Sanjuán 2016; Luciañez-Triviño\& García Sanjuán 2016). One of them was decorated with ivory discs and the other had an ivory mouth (Fig. 15). Various other objects were placed in front of the stela, including a possible semicircular box (similar to a kitchen salt-shaker) with an ivory lid (Fig. 16). Thus, the Montelirio ivories seem to constitute a collective offering, as would be the case with the 'treasure' or the furniture of a temple, rather than the expression of individual wealth. In fact, the human contingent found inside the Large Chamber of Montelirio was interpreted as a group of religious specialists ('priestesses') connected with a temple, sanctuary or oracle (García Sanjuán et al. 2016a, 544-5).

\section{Discussion}

We can summarize the results of the analysis presented above as a series of short points:

1. Since c. 3000-2900 BCE, elephant tusks were making their way into Valencina from Africa and the Near East. 


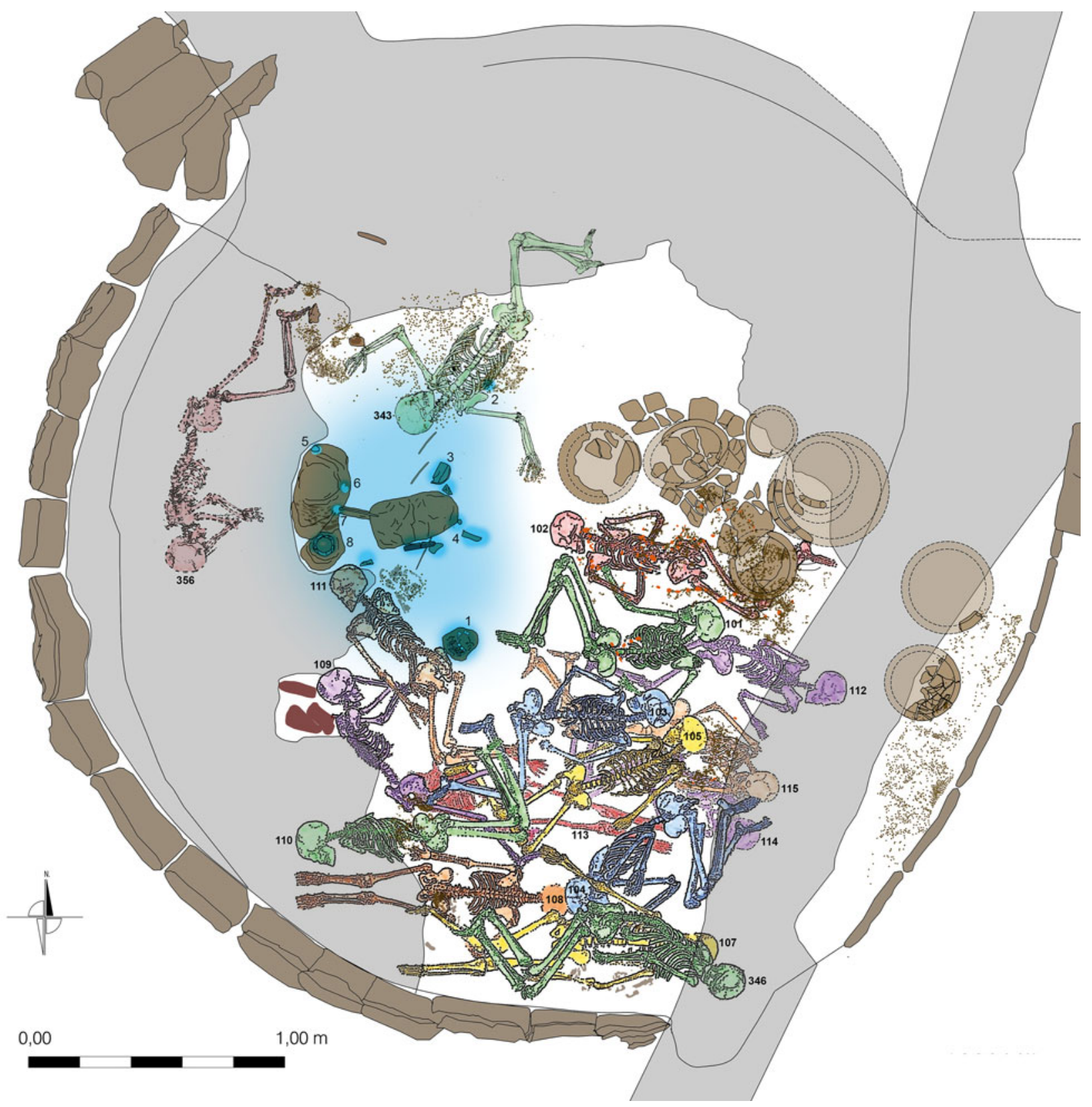

Figure 13. Location of the ivories in the Large Chamber of Montelirio. In blue, the area with the highest concentration. (1) comb with six zoomorphs; (2) acorn; (3) semicircular lid; (4) unrecognizable remains; $(5,6,7)$ discs with central perforation; (8) mouth of container. (Source: modified from a drawing by Juan Manuel Guijo Mauri.)

2. Together with this foreign material, fossil ivory also was being used. The origin of this fossil material is under study, and could have been equally imported or extracted from local sources: several remains of Elephas (Palaeoloxodon) antiquus and other megaherbivores are documented in the Las Jarillas terrace, c. $17 \mathrm{~km}$ from Valencina (Baena-Escudero et al. 2014). 3. Tusks were worked by highly skilled craftspeople who applied unrivalled expertise to produce artefacts unknown both in Iberia and western Europe.
4. While transformation debris has been identified in various simple pits (IES and DIA sectors), finished objects (and especially the most sophisticated ones) are only found in major megalithic tombs such as Montelirio, Matarrubilla and Structure 10.049.

5. Ivory was a high-end commodity, on account both of the intrinsic value of the raw material and the specialized and highly skilled labour invested into it. Thus, it was used by the local elites to sustain and reinforce their social position. This is 


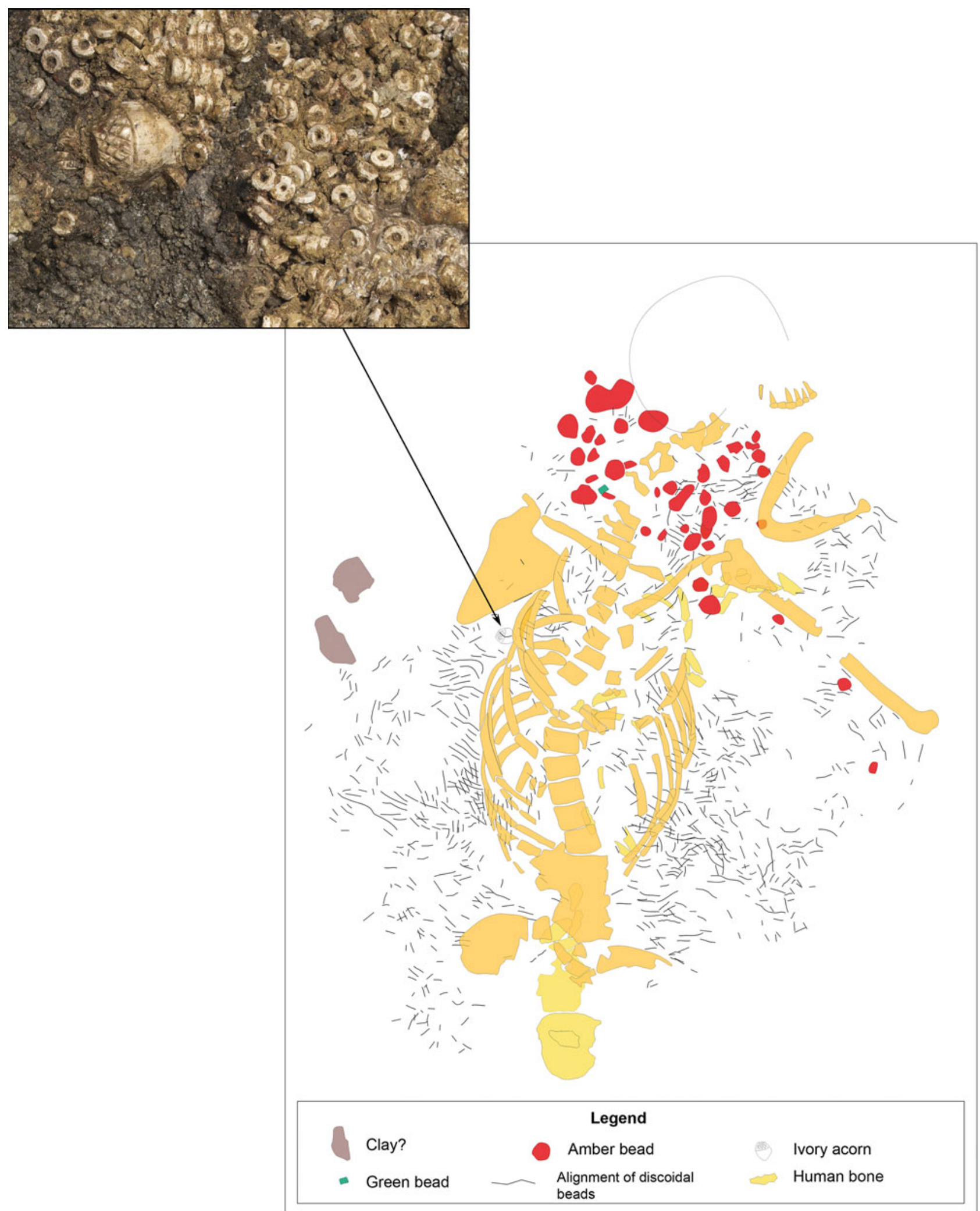

Figure 14. Acorn embedded in the costume (UE344) of a female individual (UE343) in the Large Chamber of Montelirio. (Source: modified from photograph by David Wheatley and design by Marta Diaz-Guardamino Uribe and David Wheatley, in Diaz-Guardamino Uribe et al. 2016, 355-6, figs 8 \& 11). 


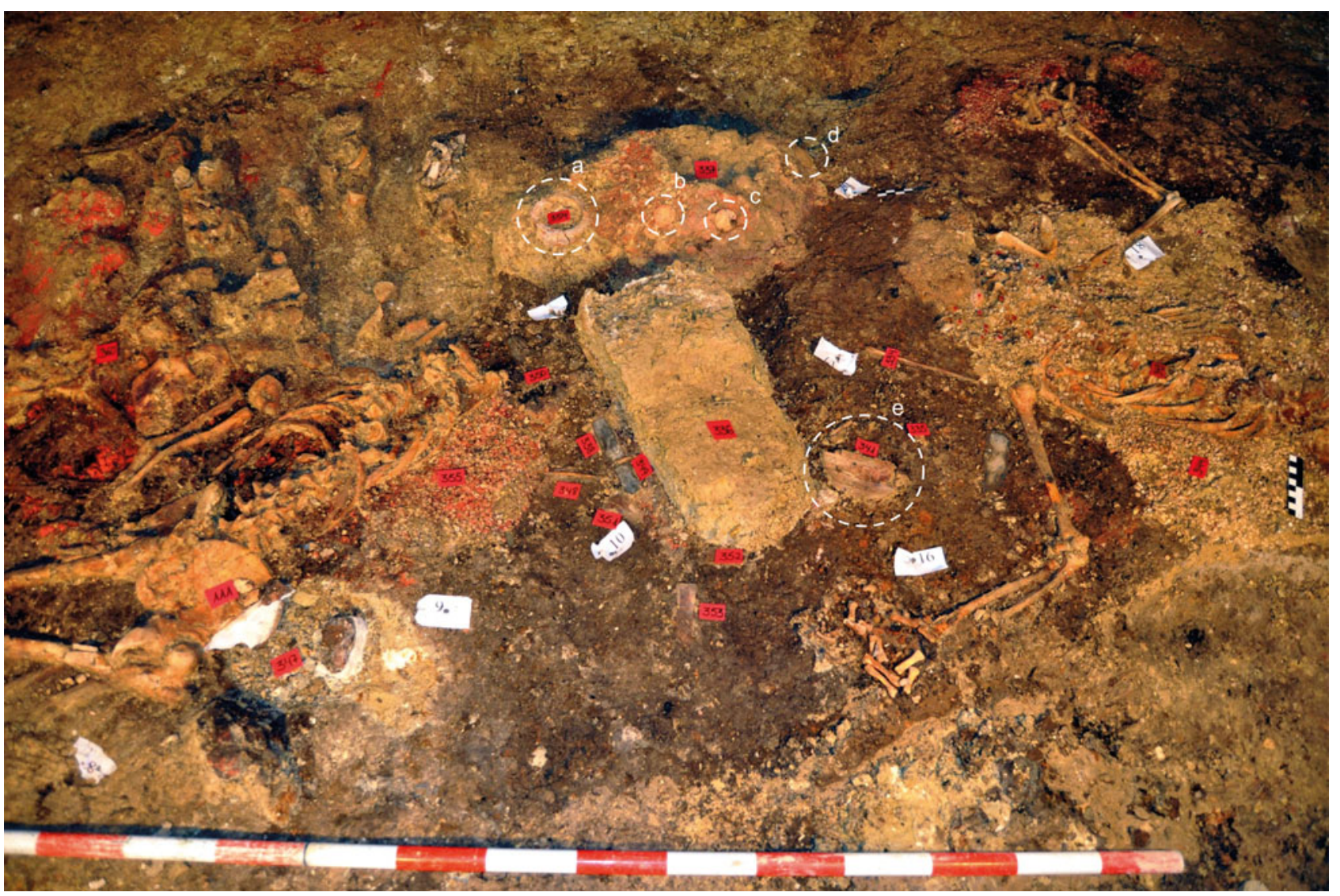

Figure 15. Montelirio tholos, Large Chamber. Location of ivory elements around the stele: (a) ivory mouth or top for container; $(b, c, d)$ ivory discs decorating a container; (e) semicircular lid. (Source: modified from a photograph by Alvaro Fernández Flores.)

particularly clear in the case of the 'Ivory Merchant', the first of what appears to be a string of powerful local leaders using ivory (in conjunction with other exotica) in large-sized, lavishly furnished megalithic tombs.

6. Ivory was not used to make utilitarian objects, but showy personal objects for display, usually attached to someone's body (combs, bracelets, pectorals, pendants and daggers).

7. Ivory was used to make distinct, unique and highly idiosyncratic artefacts which, apparently, were made only once, and for specific kinship units or corporate groups.

8. Tusk segments and whole tusks were seen as highly valuable elements per se, as demonstrated by the fact that they never appear in the simple pits that contain only production debris, but, on the contrary, feature prominently among the grave goods of high-ranking individuals, including, especially, the 'Ivory Merchant' and the two people buried in the Small Chamber of Montelirio.
Indeed, a striking characteristic of the Valencina ivory collection is that the exception appears to have been the rule. First, objects are unique; second, assemblages are singular and unrepeatable. Many of the objects found in Valencina are unique for this chronology, not only in the Iberian Peninsula, but, as far as we know, also in Europe and the western Mediterranean. The combs with zoomorphic decoration from Montelirio have no parallels in Valencina or in Iberia (Luciañez-Triviño \& García Sanjuán 2016), nor do the container lids and mouths or the perforated discs; the possible pectoral found at Matarrubilla is also unique (Schuhmacher 2012a; Schuhmacher et al. 2013a), as are the ivory dagger hilt and sheath and the decorated tusk from Structure 10.049 (García Sanjuán et al. 2013) or the small rectangular boxes.

In Structure 10.042-10.049, objects are larger and they are covered by profusely applied decoration, always using geometric and linear motifs (such as herringbone, opposite zigzags, or mesh, diamond 


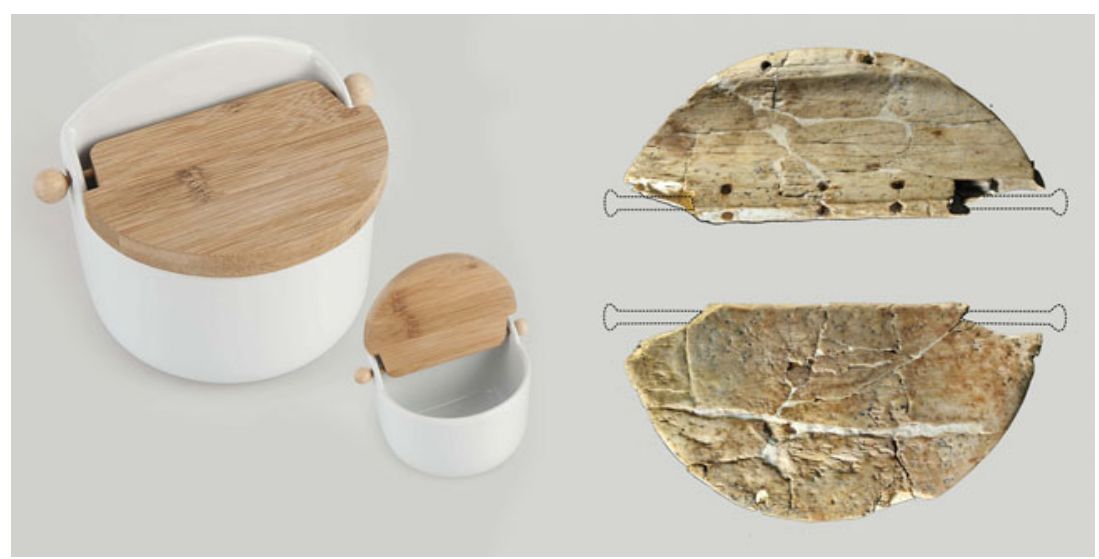

Figure 16. (Right) ivory semicircular lid, with (left) a hypothetical interpretation. and rhomboid patterns). By contrast, three generations later, the size of the objects in the Montelirio tholos decreases and those decorations become anecdotal, as they appear only in some small comb fragments in the Small Chamber (Luciañez-Triviño \& García Sanjuán 2016, 254, fig. 5). In Montelirio the main motifs are plants and animals (possible suids, a bird and acorns), which did not feature in the earlier assemblage of Structure 10.049. Later on, the size of the Matarrubilla objects is even smaller and none of those decorative motifs appear. Here the artefacts are smooth and the only decoration motif is barrelvaults. Only two fragments of a bracelet in Matarrubilla have a herringbone-like decoration pattern, but their composition and execution have nothing to do with earlier items bearing these decorations.

Therefore, we observe that in the oldest burials, more 'traditional' decorations (geometric, diamonds, etc.) were present, but as time went on, they ended up disappearing. In this sense, Montelirio started a new and different decorative tradition inspired by natural elements, although other, more general cultural features were still present. The ivory objects from Matarrubilla, however, do not appear to display continuity with either 10.049 or Montelirio; decorations disappear and items become smaller (almost exclusively beads), which is in line with the general evolution observed in ivory objects from the middle of the third millennium BCE onwards.

The clearly unique character of those three assemblages reveals the intention to create idiosyncrasies through the production and exhibition of original and unrepeatable sophisticated paraphernalia (Fig. 17). However, subtle coincidences point to a close relationship of the groups represented in each tholos with previous lineages, or individuals/groups buried in other structures. This relationship has already been suggested for Structure 10.042-10.049 and the Montelirio tholos (García Sanjuán et al. 2018b), in particular between two of the chambers of both these structures. In the Small Chamber of Montelirio and Structure 10.049, unworked tusks, objects with geometrical decoration and only one or two individuals were buried (García Sanjuán et al. 2018b, 44; Fig. 17). Another grave also located in the province of Seville presents important parallels with Structure 10.042-10.049: La Molina (Lora de Estepa). La Molina is an artificial cave, or 'hypogeum', where 10 individuals were buried. Among them, a young woman called 'E1', who probably was the last burial in the structure, had the only personalized set of grave goods, laid around her head (Juarez Martín et al. 2010, 66). Two ivory objects of La Molina's woman E1 connect her with the material culture found in the upper level of Structure 10.049: a hollowed-out and carved, cornucopia-like elephant tusk and one ivory hilt for a flint blade (García Sanjuán et al. 2018b,c). The cornucopia-like object of La Molina is smaller (García Sanjuán et al. 2018b, 53, fig. 25) and is not completely decorated (only few lines in the open end) and the handle is completely different to the one from structure 10.049, but the similarities between these objects, both in shape or functionality, suggests some degree of temporal, cultural and social proximity between the tombs and a possible connection between the two individuals (the woman E1 of La Molina and the 'Ivory Merchant'), which has been interpreted in terms of kinship or social bonds (García Sanjuán et al. 2018b, 52).

Naturally, Valencina did not exist in isolation. In the early centuries of the third millennium BCE, ivory was being consumed at other sites of southern Iberia, notably in Los Millares (southeast Spain) or Perdigões (south Portugal), with which the Valencina ivories display very few but significant connections. Despite the striking innovations, Valencina was part of a common Late Neolithic/ 
Figure 17. Idealized drawing of the possible use of some of the ivory objects. (Above) Ornamental comb with zoomorphic decoration from Large Chamber of Montelirio. (Left) Rock crystal dagger with ivory hilt carried inside its ivory and leather cloth sheath (based on some depictions in Bronze Age stelae) from the upper level of structure 10.049. (Right) Pectoral of adjacent-barrel-vaults beads from the corridor of Matarrubilla. (Source: García Sanjuán et al. 2018c. Drawings by Miriam Luciañez-

Triviño.)
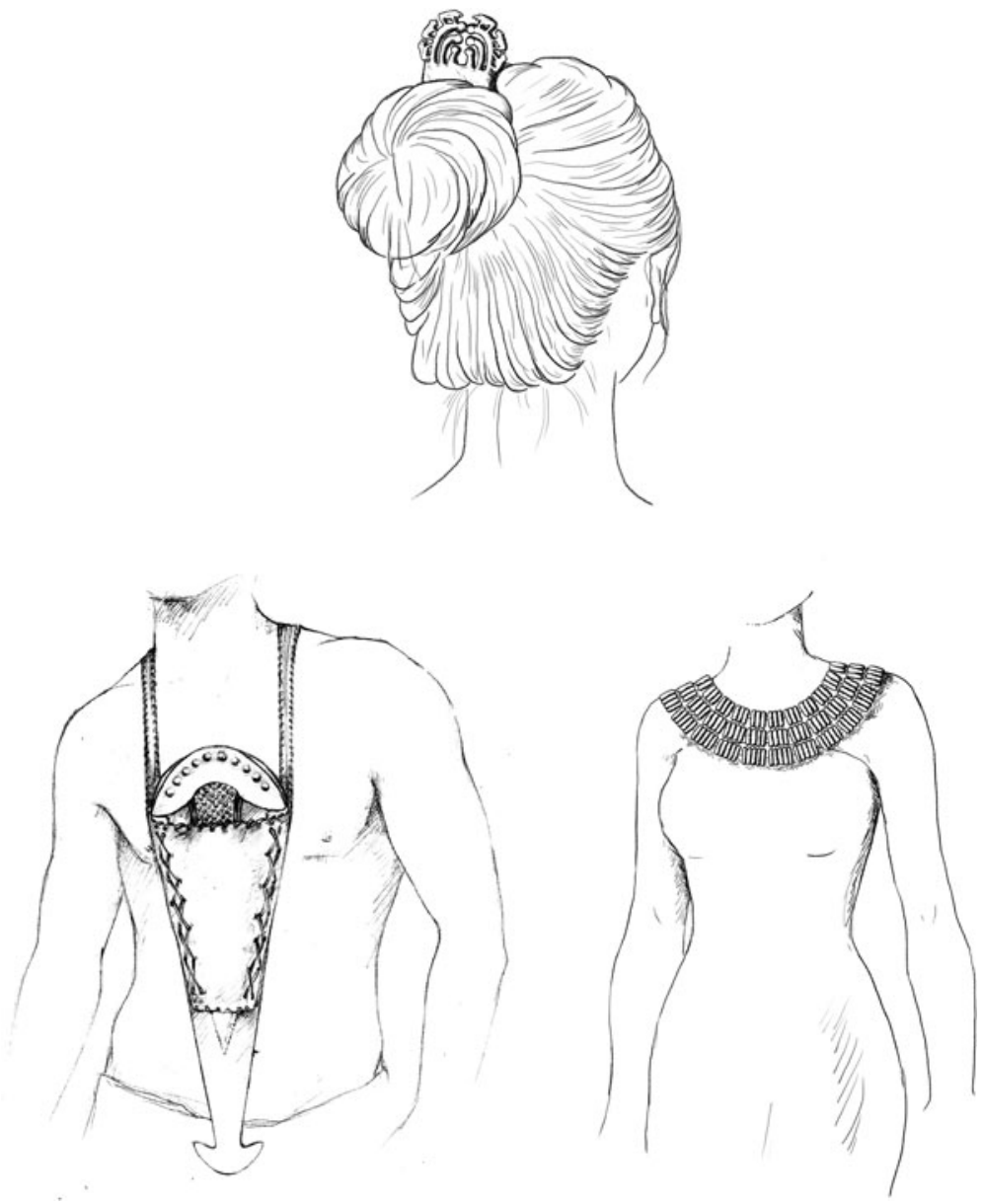

Early Chalcolithic tradition that is noticeable in some specific features of the ivories. In general, diamond and rhomboid decorations are found throughout southern Iberia. We see them in many different raw materials, such as bone, ivory, ceramics or stone (Leisner \& Leisner 1943), and particularly in vessels or cylinders made from bone and ivory, which are also abundant in Portugal, for example in Pai Mogo (Laurinha) (Gallay et al. 1973) or in Perdigões (Valera et al. 2015). Although abundant acorn-shaped pendants are found only in Montelirio (plus a possible one in the Depósito de Agua tholos), there are other specimens in southern Spain, such as those from Cueva Antoniana (Gilena, Seville) (Cruz-Auñón Briones \& Rivero Galán 1987), La Pijotilla (Badajoz), Los Algarbes (Tarifa, Cádiz) (Posac Mon 1975, 113) and El Toro cave (Antequera, Málaga) (Bueno Ramírez et al. 2016, 384; Camalich Massieu et al. 1987). There is also a possible example in Monte Abrão (Portugal) (Schuhmacher 2012a, 141, fig. 42.2, pl. 2.15).
One of Valencina's most important connections with other sites is one decorated ivory comb found in Structure 10.049 (upper level, UE535, no human remains), which is almost identical to an ivory comb from Los Millares Tomb 12 (collective burial, 12 individuals: Leisner \& Leisner 1943, 25, and pl. 11, no. 26; Maicas Ramos 2007, 122) (Fig. 18) and in which, in addition, an ivory plaque with $\mathrm{V}$-perforations on the back was also found. This draws an interesting connection with the 'Ivory Merchant'. A number of tombs at Los Millares stand out for the quantity and diversity of objects (Chapman 1990), including all those with ivory (\#5, \#7, \#8, \#9, \#12, \#16, \#40 and \#63, except for grave \#71 of doubtful attribution: Schuhmacher 2012a, 47). Ivory must have played a significant role in the definition and exhibition of power at Los Millares and other sites too.

Despite the meagre published contextual data, the anthropomorphic figurine of PP-Matarrubilla has special relevance for being the only human figure carved in ivory to date in Valencina. Other anthropomorphic figurines of the same style have been found 


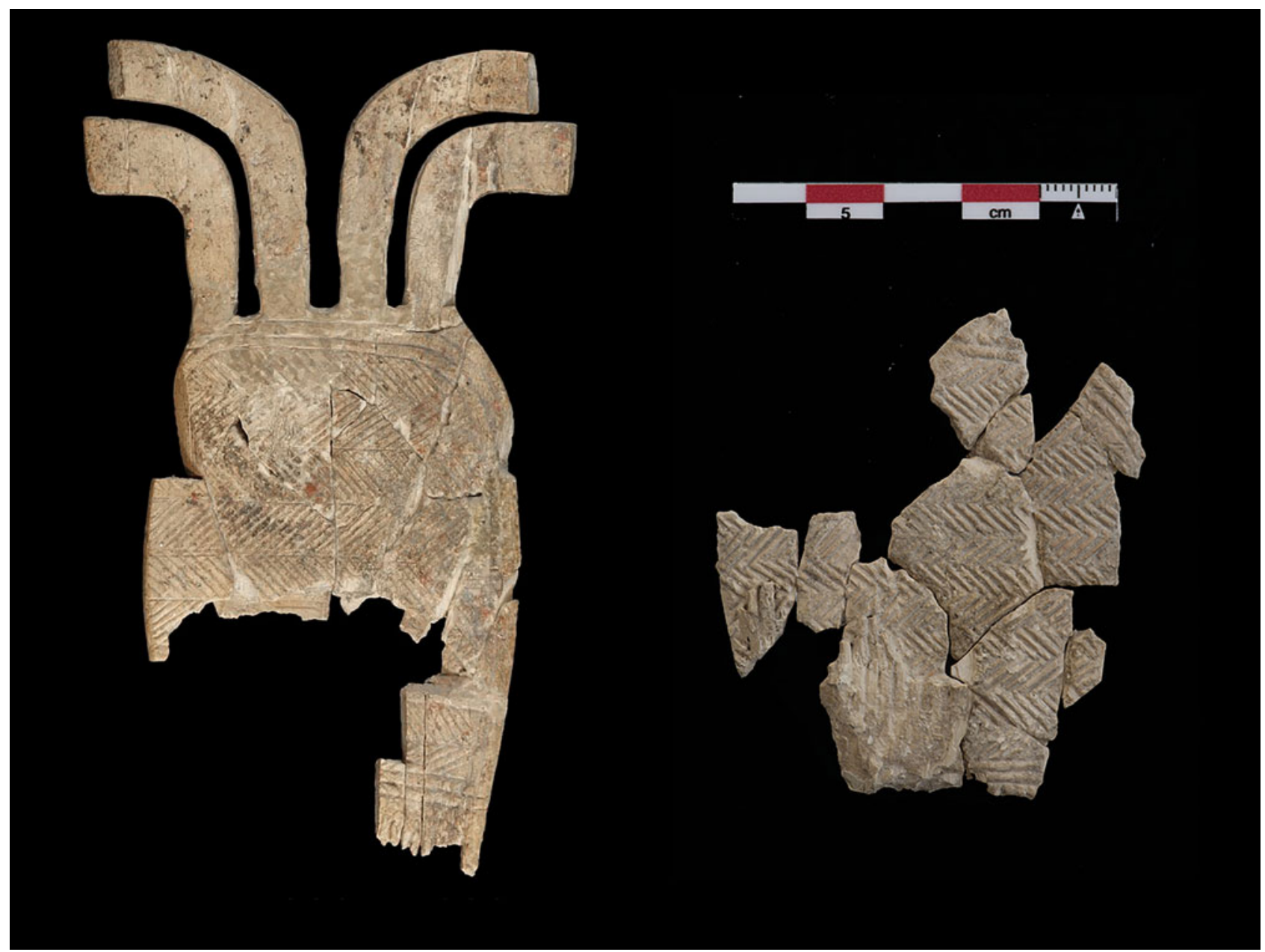

Figure 18. (Left) Comb from Tomb 12 of Los Millares. (Right) Fragments after restoration of the comb from Structure 10.049(UE535).

in other sectors of Valencina, such as the two from Shaft 1 of Cerro de la Cabeza (Fernández Gómez \& Oliva Alonso 1980, fig. 4; 1986, 28; Hurtado Pérez 2013) but they are made of bone or antler. In Iberia, this type of human representation, with hieratic pose and arms crossed on the belly, is made of various raw materials. Of ivory they are abundant in cremation contexts of Perdigões (Valera et al.2015). Other examples have been documented in Marroquíes Altos and Torre del Campo (Jaén), and in La Pijotilla (Badajoz) (Schumacher 2012a, 52).

\section{Fragmentation and biographies}

The striking contrast between the great morphological variability and the technological uniformity in Valencina's ivory assemblage suggests that the marked differences in the morphology of the objects were a deliberate choice. In this context, when the exception is the rule, then coincidences have a special significance.

The treatment, manipulation and alteration of the primary deposits of human skeletal remains is a proven practice in Valencina, and in other Copper Age contexts. This entailed the opening of burials for the disposal of new bodies, the relocation of existing ones and the selection of some parts (like skulls or long bones). If this was done with human bodies, why not think that a similar practice (of selection and transfer) may have occurred with objects? The subtle coincidences between the material culture recovered from some of the tholoi point out in this direction. The longbarbed arrowheads, white discoidal beads and fragments of small D-section rings found in structure 10.042, in the upper level of 10.049 and in Montelirio suggest a re-opening of the grave of the 'Ivory Merchant' when Montelirio was built (or used); likewise, the fragment with perforations of 
the corridor of Matarrubilla, which refers particularly to the racquet-likepiece found in the Large Chamber of Montelirio, and the deposition of blocks in Matarrubilla, Montelirio and Structure 10.042-10.049 suggest an awareness and even a relationship between the builders and users of these monuments, and perhaps other structures in the site. Ivory objects played an important role in these dynamics. Is it possible that the fragment of Matarrubilla is in fact a part of Montelirio's racquet-like piece? Could the small ring fragments be part of the same object, fragmented and then distributed between Structure 10.04210.049 and Montelirio? Or could the fragmented blocks come in some cases from the same tusk? At this time, these are just hypotheses. It has not been possible to reconstruct the rings, since they are very uniform, which makes it difficult to reassemble the pieces in their original form. The rings from Montelirio and Structure 10.042-10.049 are morphologically so similar that they cannot be distinguished from one another (García Sanjuán et al. 2018c, 45, see fig. 18).

In particular, the perforated plaque fragments found in Matarrubilla and Montelirio reveal evidence to support this theory (Fig. 19):

(I) Their shape and the arrangement of the perforations are coincident;

(II) Both are made on longitudinal plates;

(III) Both preserve part of the cementum of the tusk in the same area;

(IV) The Montelirio piece increases in thickness from the perforated part to the more distal end: the thickness of the section increases from $3.13 \mathrm{~mm}$ to $6.6 \mathrm{~mm}$, while the Matarrubilla fragment is $6.63 \mathrm{~mm}$ thick. Although we have not been able to refit one piece completely with the other, these clues point to the possibility that both pieces are fragments of the same object that would have been symmetrical, with two ends in the form of a circle joined by a straight shaft, which would be in this case thicker at one end (max. $6.63 \mathrm{~mm}$ ) and thinner at the other ( $\min .3 .13 \mathrm{~mm}$ ).

All of this echoes the words of Bollong (1994) when discussing 'category 2 ' fragmentation of ceramics, whereby no physical re-fit but similarity of morphological characteristics indicates 'sherds' from the same area of a common vessel. In fact, the Matarrubilla plaque fragment (referred to in the bibliography as a 'sandal-shaped idol') has already been claimed to be older than the context in which it was found (Schuhmacher et al. 2013a, 498) and as we have mentioned, its unusual deposition in the corridor, and therefore outside the 'traditional'

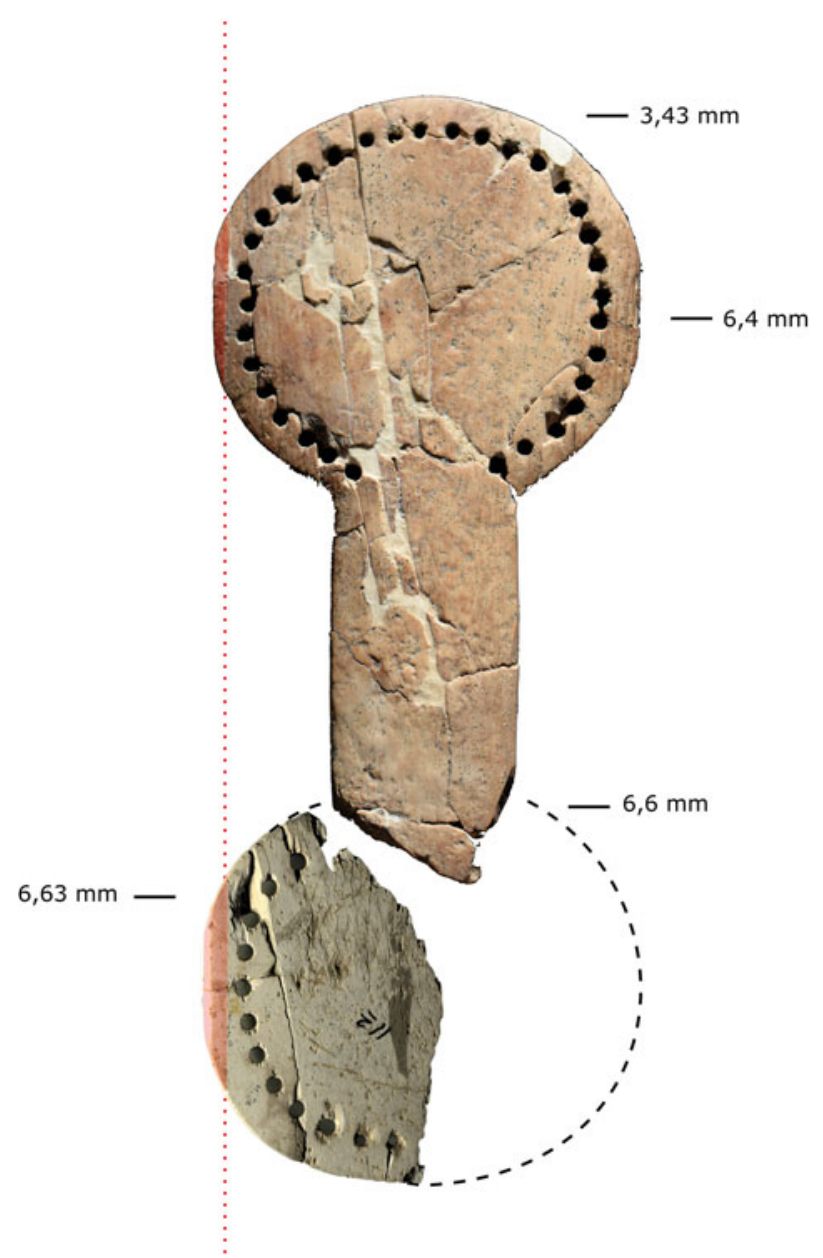

Figure 19. Racquet-like artefact from the Large Chamber of Montelirio (upper) and from the corridor of Matarrubilla (lower). With a line and in millimetres is the thickness of the piece at the indicated height. The cementum identified in the fragments is indicated in red.

deposition zone (the chambers), could point in the same direction.

Furthermore, the remains of elephant tusks from these three structures could also point to an act of intentional fragmentation. The tusk segment from the Matarrubilla corridor is from Elephas (Palaeloxodon) antiquus (García Sanjuán et al. 2013, 623, table 2; Schuhmacher 2012a,b) as would also be the case with the tusk/tusks deposited in the Small Chamber of Montelirio (Pajuelo Pando 2016). Could this be taken to mean that at some point the users of Matarrubilla fragmented the Montelirio tusk/tusks and deposited a segment in Matarrubilla?

For the time being, the impossibility of physically refitting the pieces, and the lack of more data on the raw material (such as DNA analysis), render 
this hypothetical. However, we believe that the aforementioned evidence may be indicative of a practice of fragmentation and redistribution of ivory objects. If we develop the implications of this hypothesis, then we could argue that there was a common practice: when a new tholos was built, a previous one was visited. Or at least, this could have happened between these three monuments for several generations. Intentional fragmentation of material culture has been widely documented in Neolithic and Copper Age Europe (Chapman 2000; Chapman \& Gaydarska 2007), including the specific case of Perdigões in the Iberian Peninsula, for which a practice of deliberate fragmentation of ivory lunulae has been suggested, as virtually no whole pieces (only one) were found (Valera 2010).

Thus, the hypothetical sequence could have been as follows: around 3000-2800 вСЕ, Structure 10.042-10.049 was built and used, in which bodies and materials were deposited during an unknown period of time. Some three generations later, Montelirio was built and used between 2800 and 2700 вСЕ. During or/and after its construction, the users of Montelirio visited nearby Structure 10.04210.049 and deposited some offerings, including a long-barbed arrowhead and white beads, while at the same time taking parts of older artefacts (fragments of combs and small D-section rings) from it. Subsequently, possibly between 2700 and 2600 вСе, the builders of Matarrubilla, or perhaps in a later re-use of this monument itself after $2500 \mathrm{BCE}$, reopened Montelirio and fragmented the plaque with perforations of the Large Chamber and one tusk of the Small Chamber to take parts of these objects to the new monument, where the deposition was made in the corridor.Therefore, the value of the ivory stemmed not only from its intrinsic value as a raw material (hardness and durability, showy white colour, and the fact that it enabled production of larger objects): time would also increase the value of some of the objects, as they gradually became relics, or heirlooms, associated to times past.

The communities that lived at and/or frequented Valencina throughout the third millennium BCE developed a special relationship with ivory and certain objects made from it: ivory gained a high symbolic value (McGhee 1977). This resulted primarily from its very nature as an inherently exotic commodity (Helms 1988) and from the skilled labour invested in its transformation into high-end idiosyncratic artefacts. Ivory came from distant worlds and was associated with large animals, unknown and never seen by most members of Iberian Chalcolithic societies. This simple fact probably invested the material with an aura of mystery, magic and maybe also danger in the eyes of the majority. That was probably also the case of sperm whale teeth, used in the same way as ivory in Chalcolithic Portugal, even if these animals could only be seen near the coast and as beached specimens. Their size, mysterious life in the sea and the ability to see them up close due to beaching probably conferred on them a mythical meaning, as happened in medieval and even modern times (Schuhmacher et al. 2013b). This could also explain the exchange of whale bones observed for the Magdalenian in the Pyrenean-Cantabrian region, besides the existence of technical reasons linked to their size (Lefebvre et al. 2021). It stands to reason that, because of its exotic provenance, ivory would have endowed the persons who dealt with it, obtained it, controlled its procurement and used it with a special power and prestige (García Sanjuán et al. 2013; 2018b,c; Schuhmacher 2017). It is even possible that individuals or parties from southern Spain travelled to northern Africa and other regions to procure the ivory or even actually participated in expeditions to chase the elephants down. The breadth and depth of exotic material at Valencina and other southern Iberian Copper Age sites leaves little doubt that sailing must have also been an important activity at the time (for a discussion of maritime sailing in thirdmillennium Iberia, see Guerrero Ayuso 2010; Schubart 1990).Therefore, there may have been an element of agency in how ivory was sought after and procured; people like the 'Ivory Merchant' must have increased their prestige or rank through their association with distant lands and, perhaps, dangerous travels-sensu Helms (1988). But the value of ivory objects also came from their histories or biographies. Once they became 'old', they evoked times past and genealogical connections, bonding people, monuments, moments and places, through an enchainment relation (Chapman 2000; Chapman \& Gaydarska 2007). In the evolution towards early social complexity, the nature of personhood was profoundly transformed (Gilman 1995, 236).

In the Guadalquivir valley, ivory appears to have played a key role in this process, helping to create a new ideology of rank. It seems that in the cases discussed here, the deposition of 'new' elements in previous structures and the collection of parts of 'ancient' objects to introduce them into more modern structures was a way to legitimize social and political strategies and a means to perpetuate the union with ancestors, or with earlier prominent lineages. As happened with other selected items (Lillios 1999), ivory objects would have been turned into heirlooms 
through the fragmentation-redistribution process described above: used first to create idiosyncrasies by which would-be and/or established leaders would attempt to construct a 'hereditary rank', and later helping to maintain them over generations.

\section{Conclusions}

Through a detailed analysis of ivory, one of the most appealing raw materials in our past as a species, we have been able to explore how material culture was used to construct cultural identities and to support political claims to prestige and power in Copper Age Iberia. Identity is constructed but bound by the cultural repertoires to which people have access and the structural context in which they live (Lamont 2001, 171). The arrival of new raw materials, objects and technologies may therefore be an opportunity for social change. During the first 200 years of activity at Valencina, reflected in burial activity at the La Huera and Calle Dinamarca hypogea (García Sanjuán et al. 2018a), no foreign imports appear to have made their way into the site. Then ivory from Africa and Asia appeared rather suddenly between 3000 and $2900 \mathrm{BCE}$, alongside other foreign imports such as ostrich eggshell or amber, and quickly became a raw material of outstanding social and ideological importance, not available to everyone. Our research reveals how ivory played an important role in the manufacture of social and ritual paraphernalia and in the crafting of idiosyncrasies. Not only are many of the site's most sophisticated personal ornaments made of ivory, but also containers for other substances deposited in the graves. Why choose ivory instead of wood or leather to make a lid or part of a container? It is very possible that not only the exoticism of the material but also its colour had something to do with the choice: together with red and black, white was one of the three most used colours in the symbolism of death in Late Neolithic and Copper Age Iberia (Bueno Ramírez et al. 2016, 397). The white of the ivory would have contrasted with the red and green tones of the objects they complemented.

Ivory was not used to make utilitarian objects. It was used to create showy personal objects intended for display, attached to someone's body, as was the case with combs, bracelets, pectorals, pendants and daggers. The vessels and the ivory elements for decoration (discs with perforation) or parts of composite objects (lids and mouths of containers) may have had a more social or collective character, like ritual furniture, perhaps belonging to a community, corporate group or ceremonial centre/structure, and not to a particular individual. An example of this would be the lids and the container mouths of Montelirio.

The identity and rank of these groups or individuals would be crafted through an incipient process of exclusion (which is intrinsic to the creation of identity: e.g. Butler 1990; Hall \& Du Gay 1996; Laclau \& Mouffe 1984; Lamont 1992; 2001). This would have

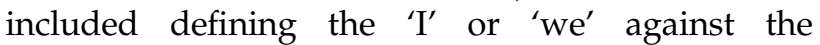
'others'-reinforcing concepts of 'Othering' and 'Otherness' which are routinely applied in the construction of identities (e.g. Brons 2015; Gonzalez Alvarez \& Alonso Gonzalez 2014; Halsall 2017; Harland 2017; Jensen 2011; Staszak 2008). The choice of unique objects in ivory and particular decorative patterns was a means of marking the identity of small specific groups, within a broader Late Neolithic/Early Copper Age tradition that persisted throughout southern Iberia. This general Chalcolithic substrate, mainly characterized by collective burials in which grave goods usually were not related to a particular person, began slowly to disintegrate with the burial of new 'special' collectives or individuals, the first of whom appears to have been the 'Ivory Merchant'. They differed from the rest of society either because of the quantity, variety and sophistication of their grave goods, or because of their unique character (i.e. individual burials with exotic grave goods). This has been interpreted as the emergence in the lower Guadalquivir River valley (between 3000 and 2600 cal. BC) of an'elite' for which ivory was precisely the common denominator (García Sanjuán et al. 2018b,c; Schuhmacher 2017).

In the specific social dynamics generated in the lower Guadalquivir valley at the start of the third millennium BCE (García Sanjuán et al. 2018b, 319), this incipient search for differentiation was not carried out abruptly. Altering or modifying living conditions always implies a risk, since only by maintaining known cultural systems is there confidence in a successful survival (Aranda Jimenez 2015, 127). Accordingly, would-be leaders, as prominent social figures of the early third millennium, needed to legitimize their position through a real or fictitious kinship relationship, in which idiosyncrasies crafted in ivory played a key role. This was made by means of the possession and exhibition of sumptuous objects made of exotic materials and the visiting and worshipping of earlier monuments, especially through the fragmentation and collection of ancient ivory objects. Ivory became a vehicle for the materialization of new ideologies and power strategies-sensu DeMarrais et al. (1996). It can be argued that it was a time of struggle and change, 
but also of persistence and resistance; in the dialectical tension between differentiation and the resistance to it, ivory played an important, dual and contrasting role: it was a means of destruction of the old order because it was used to craft new identities, but at the same time, it was a vehicle of legitimation of these new roles/identities, since these individuals needed to secure their position by claiming a bond with their ancestors.

\section{Note}

1. They are the only two structures that have detailed field documentation, and therefore allow a more accurate interpretation.

\section{Acknowledgements}

This research has been carried out thanks to two research grants-grant numbers BFI-2012-261 (Predoc) and POS-2018-1-0074 (Postdoc)-funded by the Basque Government awarded to M. Luciañez-Triviño, and has been developed within the Prehistoric Research Consolidated Group of the Basque Country University UPV/EHU (IT1223-19). We thank the staff of the Museums of Seville and Valencina, as well as all the archaeologists who have provided material and support for the study. Many thanks also to Professor Timothy Earle and Dr Marta Díaz-Guardamino Uribe for their feedback on earlier drafts of this paper.

Miriam Luciañez-Triviño Department of Geography, Prehistory and Archaeology University of the Basque Country UPV/EHU C/ Tomás y Valiente s/n 01006 Vitoria-Gasteiz Spain $\mathcal{E}$

Institutfür Ur- und Frühgeschichte und Archäologie des Mittelalters Eberhard-Karls-Universität Tübingen Germany Email:miriam.lucianez@ehu.eus,mlucianez@us.es

Leonardo García Sanjuán Department of Prehistory and Archaeology University of Seville C/ María de Padilla s/n 41004 Sevilla Spain

Email:lgarcia@us.es

Thomas Schuhmacher Deutsches Archäologisches Institut C/ Serrano 159

\author{
28002 Madrid \\ Spain \\ Email:Thomas.Schuhmacher@dainst.de
}

\section{References}

Ábelová, M., 2008. Schreger pattern analysis of Mammuthus primigenius tusk: analytical approach and utility. Bulletin of Geosciences 83(2), 225-32.

Altamirano García, M. \& M. Luciañez-Triviño, 2016. La industria en hueso del tholos de Montelirio [The bone industry of the tholos of Montelirio], in Montelirio: Un Gran Monumento Megalítico de la Edad del Cobre [Montelirio. A great megalithic monument of the Copper Age], eds A. Fernández Flores, L. García Sanjuán \& M. Díaz-Zorita Bonilla. Seville: Junta de Andalucía, 273-83.

Aranda Jiménez, G., 2015. Resistencia e involución social en las comunidades de la Edad del Bronce del sureste de la Península Ibérica [Resistance and social involution in the Bronze Age communities of the southeastern Iberian Peninsula.]. Trabajos de Prehistoria 72 (1), 126-44.

Arteaga Matute, O. \& R. Cruz-Auñón Briones, 2001. Las nuevas sepulturas prehistóricas (tholoi) y los enterramientos bajo túmulos (tartesios) de Castilleja de Guzmán (Sevilla). Excavación de urgencia [The new prehistoric burials (tholoi) and tumuli (Tartessian) of Castilleja de Guzmán (Seville). Emergency excavation]. Anuario Arqueológico de Andalucía 1996 (2001), 640-51.

Averbouh, A., 2001. Methodological specifics of the techno-economic analysis of worked bone and antler: mental refitting and methods of application, in Crafting Bone: Skeletal technologies through time and space, eds A.M. Choyke \& L. Bartosiewicz. (BAR International series S937.) Oxford: BAR Publishing, $111-22$.

Baena Escudero, R., J.J. Fernández Caro, I. Guerrero Amador \& J.C. Posada Simeón, 2014. La Terraza compleja del río Gualdaquivir en 'Las Jarillas' (La Rinconada, Sevilla. SW de España): Crono-estratigrafía, industrialítica y macro-fauna asociada [The complex terrace of the Gualdaquivir river at 'Las Jarillas' (La Rinconada, Seville. SW Spain): Chronostratigraphy, lithic industry and associated macrofauna.]. Cuaternario y Geomorfología 28 (3-4), 107-25.

Barciela González, V., 2007. El trabajo del marfil en la prehistoria reciente de la región central del mediterráneo peninsular: análisis tecnológico y experimental de los adornos personales [Ivory working in late prehistory of the central region of the peninsular Mediterranean: technological and experimental analysis of personal ornaments.], in Arqueología experimental en la Península Ibérica: investigación, didáctica $y$ patrimonio [Experimental archaeology in the Iberian Peninsula: research, didactics and heritage], eds M.L. Ramos Sainz, J.E. González Urquijo \& 
Crafting Idiosyncrasies. Early Social Complexity, Ivory and Identity-Making in Copper Age Iberia

J. Baena. Santander: Asociación Española de Arqueología Experimental, 265-74.

Barciela González, V., 2012. Tecnología del marfil en la Edad del Bronce de la meseta sur (España) [Ivory technology in the Bronze Age of the Southern Plateau (Spain)], in Elfenbeinstudien. Faszikel 1: Marfil y Elefantes en la Península Ibérica y el Mediterráneo, Actas del coloquio internacional en Alicante el 26 y 27 de noviembre 2008 [Ivory Studies, Fascicle 1: Ivory and Elephants in the Iberian Peninsula and the Mediterranean, Proceedings of the international colloquium in Alicante on 26 and 27 November 2008], eds A. Banerjee, J.A. López Padilla \& T.X. Schuhmacher. (Iberia Archaeologica 16(1).) Darmstadt: Philipp von Zabern, 199-214.

Barciela González, V., 2015. El lenguaje de los adornos: tecnología, uso y función. Adornos personales de la Edad del Bronce en Alicante y Albacete [The language of ornaments: technology, use and function. Personal ornaments of the Bronze Age in Alicante and Albacete.]. PhD dissertation, University of Alicante.

Bollong, C.A., 1994. Analysis of the stratigraphy and formation processes using patterns of pottery sherd dispersion. Journal of Field Archaeology 21, 15-28.

Brons, L. 2015. Othering, an analysis. Transcience 6(1), 6990.

Bueno Ramírez, P., R. Balbín Behrmann, R. Barroso Bermejo, F. Carrera Ramírez \& M. Hunt Ortiz, 2016. El arte y la plástica en el tholos de Montelirio [Art and sculpture in the tholos of Montelirio], in Montelirio: Un Gran Monumento Megalítico de la Edad del Cobre [Montelirio. A great megalithic monument of the Copper Age], eds A. Fernández Flores, L. García Sanjuán \& M. Díaz-Zorita Bonilla. Seville: Junta de Andalucía, 365-405.

Butler, J., 1990. Gender Trouble: Feminism and subversion of identity. New York (NY): Routledge.

Camalich Massieu, M.D., P. Gonzalez Quintero \& D. Martín Socas, 1987. Informe preliminar de la campaña de 1985 en la Cueva del Toro de El Torcal (Antequera) [Preliminary report of the 1985 campaign in the Cueva del Toro in El Torcal (Antequera).]. Anuario Arqueológico de Andalucía 1985, Tomo II Actividades Sistemáticas, 233-40.

Camps, G., 1960. Les traces d'un Age du Bronze en Afrique du Nord [Traces of a Bronze Age in north Africa]. Revue Africaine 104, 31-55.

Cardoso, J.L. \& TX. Schuhmacher, 2012. Marfiles calcolíticos en Portugal. Estado de la cuestión [Chalcolithic ivories in Portugal. State of the art], in Elfenbeinstudien. Faszikel 1: Marfil y Elefantes en la Península Ibérica y el Mediterráneo, Actas del coloquio internacional en Alicante el 26 y 27 de noviembre 2008 [Ivory Studies, Fascicle 1: Ivory and Elephants in the Iberian Peninsula and the Mediterranean, Proceedings of the international colloquium in Alicante on 26 and 27 November 2008], eds A. Banerjee, J.A. López Padilla \& $T$.
X. Schuhmacher. (Iberia Archaeologica 16(1).) Darmstadt: Philipp von Zabern, 95-110.

Chapman, J., 2000. Fragmentation in Archaeology: People, places and broken objects in the prehistory of southeastern Europe. London: Routledge.

Chapman, J. \& G. Gaydarska, 2007. Parts and Wholes: Fragmentation in prehistoric context. Oxford: Oxbow.

Chapman, R., 1990. Emerging Complexity.The later prehistory of south-east Spain, Iberia and the west Mediterranean. Cambridge: Cambridge University Press.

Choyke, A. \& S. O'Connor (eds), 2013. From these Bare Bones. Raw materials and the study of worked osseous objects. Oxford: Oxbow.

Christensen, M., 1999. Technologie de l'ivoire au Paléolithique supérieur: Caractérisation physico-chimique du matériau et analyse fonctionnelle des outils de transformation [Ivory technology in the Upper Palaeolithic: Physicochemical characterisation of the material and functional analysis of tools]. (BAR International series S751.) Oxford: Archaeopress.

Collantes de Terán, F., 1969. El dolmen de Matarrubilla [The dolmen of Matarrubilla], in Actas del $V$ Symposium Internacional de Prehistoria Peninsular. Tartessos y Sus Problemas (Jerez, 1968) [Proceedings of the V International Symposium on Peninsular prehistory. Tartessos and its Problems (Jerez, 1968)]. Barcelona: Universidad de Barcelona, 47-61.

Costa Caramé, M.E., M. Díaz-Zorita Bonilla, L. García Sanjuán \& D.W. Wheatley, 2010. The Copper Age settlement of Valencina de la Concepción (Seville, Spain): demography, metallurgy and spatial organization. Trabajos de Prehistoria 67(1), 87-118.

Cruz-Auñón Briones, R. \& E. Rivero Galán, 1987. Gilena. Un foco de especial interés para el estudio de la Edad del Cobre en Andalucía. Cueva artificial de Antoniana [Gilena. A focus of special interest for the study of the Copper Age in Andalusia. Antoniana artificial cave]. Gilena: Ayuntamiento de Gilena y Diputación Provincial de Sevilla.

DeMarrais, E., L.J. Castillo \& T. Earle, 1996. Ideology, materialization and power strategies. Current Anthropology 37(1), 15-31.

Deschler-Erb, S., 1998. Römische Beinartefakte aus Augusta Raurica: Rohmaterial, Technologie, Typologie und Chronologie [Roman bone artefacts from Augusta Raurica: raw material, technology, typology and chronology]. Augst: Römermuseum.

Díaz-Guardamino Uribe, M., D. Wheatley, E. Williams \& J. A. Garrido Cordero, 2016. Los textiles elaborados con cuentas perforadas de Montelirio [Montelirio textiles made with perforated beads], in Montelirio: Un Gran Monumento Megalítico de la Edad del Cobre [Montelirio. A great megalithic monument of the Copper Age], eds A. Fernández Flores, L. García Sanjuán \& M. Díaz-Zorita Bonilla. Seville: Junta de Andalucía, 345-64.

Espinoza, E.O \& M. Mann, 1991. Identification Guide for Ivory and Ivory Substitutes. Richmond: World Wildlife Fund \& Conservation Foundation. 
Espinoza, E.O \& M. Mann, 1993. The history and significance of the Schreger pattern in proboscidean ivory characterization. Journal of the American Institute for Conservation 32(3), 241-8.

Espinoza, E.O \& M. Mann, 1999. Guía para la identificación del marfil y los substitutos del marfil [Identification guide for ivory and ivory substitutes]. Richmond: World Wildlife Fund \& Conservation Foundation.

Feldhamer, G.A., L.C. Drickamer, S.H. Vessey, J.F. Merritt \& C. Krajewski, 1999. Mammalogy: Adaptation, diversity, and ecology. Boston (MA): McGraw-Hill.

Fernández Flores, A. \& L. García Sanjuán, 2016. Arquitectura, estratigrafía y depósitos del tholos de Montelirio [Architecture, stratigraphy and deposits of the tholos of Montelirio], in Montelirio: Un Gran Monumento Megalítico de la Edad del Cobre [Montelirio. A great megalithic monument of the Copper Age], eds A. Fernández Flores, L. García Sanjuán \& M. Díaz-Zorita Bonilla. Seville: Junta de Andalucía, 79-141.

Fernández Flores, A., L. García Sanjuán \& M. Díaz-Zorita Bonilla (eds.), 2016. Montelirio: Un Gran Monumento Megalítico de la Edad del Cobre [Montelirio. A great megalithic monument of the Copper Age]. Seville: Junta de Andalucía.

Fernández Gómez, F. \& D. Oliva Alonso, 1980. Los ídolos calcolíticos del Cerro de la Cabeza (Valencina de la Concepción, Sevilla) [The Chalcolithic idols of Cerro de la Cabeza (Valencina de la Concepción, Seville)]. Madrider Mitteilungen 21, 20-44.

Fernández Gómez, F. \& D. Oliva Alonso, 1986. Valencina de la Concepción (Sevilla). Excavaciones de urgencia [Valencina de la Concepción (Sevilla). Emergency excavations]. Revista de Arqueología, 58, 19-33.

Fitton, J.L., 1992. Ivory in Greece and the Eastern Mediterranean from the Bronze Age to the Hellenistic Period. London: British Museum Press.

Gallay, G., C. Sindler, L. Trindade \& E.O. Da Veiga Ferreira, 1973. O Monumento Préhistorico de Pai Mogo (Lourinha) [The prehistoric monument of Pai Mogo (Lourinha)]. Lisbon: Associaçao dos arqueólogos portugeses.

García Sanjuán, L. 2013. El asentamiento de la Edad del Cobre de Valencina de la Concepción: estado actual de la investigación, debates y perspectivas [The Copper Age settlement of Valencina de la Concepción: current state of the research, debates and prospects], in El asentamiento prehistórico de Valencina de la Concepción (Sevilla): investigación y tutela en el 150 aniversario del descubrimiento de La Pastora [The prehistoric settlement of Valencina de la Concepción (Seville): research and guardianship on the 150th anniversary of the discovery of La Pastora], eds L. García Sanjuán, J.M. Vargas Jiménez, V. Hurtado Pérez, T. Ruiz Moreno \& R. Cruz-Auñón Briones. Seville: Universidad de Sevilla, 21-59.

García Sanjuán, L. 2017. Farming economy and wealth economy in the Copper Age of the Lower Guadalquivir River: debating strategic resources at Valencina de la
Concepción (Seville, Andalusia, Spain), in Key Resources and Socio-Cultural Developments in the Iberian Chalcolithic, eds M. Bartelheim, O. Bueno Ramírez \& M. Kunst. Tübingen: University of Tübingen, 237-56.

García Sanjuán, L., M. Cintas-Peña, M. Bartelheim \& M. Luciañez-Triviño, 2018b. Defining the 'elites' a comparative analysis of social ranking in Copper Age Iberia, in Überschuss ohne Staat - Politische Formen in der Vorgeschichte: 10. Mitteldeutscher Archäologentag vom 19. bis 21. Oktober 2017 in Halle (Saale) [Surplus without the State - Political forms in Prehistory International Archaeological Conference of Central Germany; 19-21 October, 2017, Halle (Saale)], eds H. Meller, D. Gronenborn \& R. Risch. Langenweißbach: Beier \& Beran, 311-33.

García Sanjuán, L., M. Cintas-Peña, M. Díaz-Guardamino Uribe, J. Escudero Carrillo, M. Luciañez-Triviño, C. Mora Molina \& S. Robles Carrasco, 2019. Burial practices and social hierarchisation in Copper Age southern Spain: analysing tomb 10.042-10.049 of Valencina de la Concepción (Seville, Spain), in Megaliths, Societies, Landscapes: Early monumentality and social differentiation in Neolithic Europe, eds J. Muller \& M. Hinz. Kiel: University of Kiel.

García Sanjuán, L., M. Cintas-Peña, C. Rodríguez-Rellán \& M. Luciañez-Triviño, (forthcoming). El Tholos de Montelirio: Nuevas Investigaciones [The tholos of Montelirio: new investigations]. Seville: Junta de Andalucía.

García Sanjuán, L., A. Fernández Flores \& M. Díaz-Zorita Bonilla, 2016a. Montelirio. Valoración e Interpretación de una tumba excepcional [Montelirio. Assessment and interpretation of an exceptional tomb], in Montelirio: Un Gran Monumento Megalítico de la Edad del Cobre [Montelirio. A great megalithic monument of the Copper Age], eds A. Fernández Flores, L. García Sanjuán \& M. Díaz-Zorita Bonilla. Seville: Junta de Andalucía, 503-53.

García Sanjuán, L., J.A. Lozano Rodríguez, O. Sánchez Lirazo, J. Gibaja Bao \& V. Aranda Sánchez, 2016b. La industria lítica del tholos de Montelirio [The lithic industry of the tholos of Montelirio], in Montelirio: Un Gran Monumento Megalítico de la Edad del Cobre [Montelirio. A great megalithic monument of the Copper Age], eds A. Fernández Flores, L. García Sanjuán \& M. Díaz-Zorita Bonilla. Seville: Junta de Andalucía, 203-44.

García Sanjuán, L., M. Luciañez-Triviño \& M. Cintas-Peña, 2018c. Ivory, elites and lineages in Copper Age Iberia: exploring the wider significance of the Montelirio tomb. Madrider Mitteilungen 59, 22-65.

García Sanjuán, L., M. Luciañez-Triviño, T. X. Schuhmacher, D.W. Wheatley \& A. Banerjee, 2013. Ivory craftsmanship, trade and social significance in the southern Iberian Copper Age: the evidence from the PP4-Montelirio sector of Valencina de la Concepción (Seville, Spain). European Journal of Archaeology 16(4), 610-35. 
García Sanjuán, L. \& M. Murillo-Barroso, 2013. Social complexity in Copper Age southern Iberia (c. 3200-2200 cal BC): reviewing the 'state' hypothesis at Valencina de la Concepción (Seville, Spain), in The Prehistory of Iberia: Debating early social stratification and the state, eds M. Cruz Berrocal, L. García Sanjuán \& A. Gilman. New York (NY): Routledge, 119-40.

García Sanjuán, L., C. Scarre \& D. Wheatley, 2017. The mega-site of Valencina de la Concepción (Seville, Spain): debating settlement form, monumentality and aggregation in southern Iberian Copper Age societies. Journal of World Prehistory 30, 239-57.

García Sanjuán, L., J.M. Vargas Jiménez, L. Cáceres Puro, et al., 2018a. Assembling the dead, gathering the living: radiocarbon dating and Bayesian modelling for Copper Age Valencina de la Concepción (Sevilla, Spain). Journal of World Prehistory 31(2), 179-313.

Gilman, A. 1995. Prehistoric European chiefdoms: rethinking 'Germanic' societies, in Foundations of Social Inequality, eds T.D. Price \& G.M. Feinman. New York (NY): Plenum, 235-51.

González Álvarez, D. \& P. Alonso González, 2014. From the cultural representation of otherness to the materialization of difference: a contemporary archaeology of domesticity among the vaqueiros d'Alzada and the Maragatos (Spain). Chungara 46(4), 607-23.

Götze, A. 1925. Elfenbein, Europa [Ivory, Europe], in Reallexikon der Vorgeschichte [Encyclopaedia of prehistory], ed. M. Ebert. Berlin: Walter de Gruyter, vol. $3,87$.

Guerrero Ayuso, V., 2010. Barcos calcolíticos (c. 2500-2000 BC) del Mediterráneo occidental [Chalcolithic boats (c. 2500-2000 BC) from the Western Mediterranean]. Pyrenae 41 (2), 29-48.

Hall, S. \& P. Du Gay (eds), 1996. Questions of Cultural Identity. London: Sage.

Halsall, G.R.W., 2017. Identity and otherness in the Merovingian cemetery, in Entangled Identities and Otherness in Late Antique and Early Medieval Europe: Historical, archaeological and bioarchaeological approaches, eds J. Lopez Quiroga, M. Kazanski \& V. Ivanisevic. (BAR International series S2852.) Oxford: BAR Publishing, 189-98.

Harland, J.M., 2017. Rethinking ethnicity and `Otherness in Early Anglo-Saxon England. Medieval Worlds 5 (5), 113-42.

Harrison, R.J. \& A. Gilman, 1977. Trade in the second and third millennia BC between the Maghreb and Iberia, in Ancient Europe and the Mediterranean: Studies in honour of Hugh Hencken, ed V. Markotic. Oxford: Aris \& Phillips, 90-104.

Haynes, G., 1991. Mammoths, Mastodonts, and Elephants: Biology, behaviour, and the fossil record. Cambridge: Cambridge University Press.

Helms, M., 1988. Ulysses' Sail: An ethnographic odyssey of power, knowledge and geographical distance. Princeton (NJ): Princeton University Press.
Hunt Ortiz, M.A., S. Consuegra Rodríguez, P. Díaz Del Río Español, V. Hurtado-Pérez \& I. Montero-Ruiz, 2011. Neolithic and Chalcolithic - VI to III millennia BC - use of cinnabar $(\mathrm{HgS})$ in the Iberian Peninsula: analytical identification and lead isotope data for an early mineral exploitation of the Almadén (Ciudad Real, Spain) mining district, in History of Research in Mineral Resources, eds J. E. Ortiz, O. Puche, I. Rábano \& L.F. Mazadiego. Madrid: Instituto Geológico y Minero de España, 3-14.

Hunt Ortiz, M. \& V. Hurtado Pérez, 2010. Pigmentos de sulfuro de mercurio (cinabrio) en contextos funerarios de época calcolítica en el Sur de la península Ibérica: investigaciones sobre el uso, depósitos minerales explotados y redes de distribución a través de la caracterización composicional e isotópica [Mercury sulphide pigments (cinnabar) in Chalcolithic funerary contexts in the south of the Iberian Peninsula: investigations on use, exploited mineral deposits and distribution networks through compositional and isotopic characterization], in Actas del VIII Congreso Ibérico de Arqueometría (Teruel, 19-21 de octubre de 2009) [Proceedings of the VIII Iberian Archaeometry Congress (Teruel, 19-21 October 2009).], eds M.E. Sainz Carrasco, P. López Romero, M.A. Cano Díaz-Tendero \& J. C. Calvo Carcía. Teruel: Seminario de Arqueología y Etnología Turolense, 123-32.

Hurtado Pérez, V., 2013. Los ídolos del asentamiento de Valencina de la Concepción: una revisión [The idols of the Valencina de la Concepción settlement: a review], in El asentamiento prehistórico de Valencina de la Concepción (Sevilla): investigación y tutela en el 150 aniversario del descubrimiento de La Pastora [The prehistoric settlement of Valencina de la Concepción (Seville): research and guardianship on the 150th anniversary of the discovery of La Pastora], eds L. García Sanjuán, J.M. Vargas Jiménez, V. Hurtado Pérez, T. Ruiz Moreno \& R. Cruz-Auñón Briones. Seville: Universidad de Sevilla, 311-27.

Ilan, D., 2013. The life and times of an ivory handle of the second millennium BCE: a tale of prestige and demise, in Alphabets, Texts and Artifacts in the Ancient Near East: Studies presented to Benjamin Sass, eds I. Finkelstein, C. Robin \& T. Römer. Paris: Van Dieren, 161-72.

Inacio, N., F. Nocete Calvo, J.M. Nieto Liñán, M. Rodríguez Bayona \& D. Abril López, 2011. From raw materials to utilisation: ceramics associated with the metallurgical activity at Valencina de la Concepcion (Seville, Spain): technological choices and social implication, in Archaeological Ceramics: A review of current research, ed S. Scarcella. (BAR International series 2193.) Oxford: BAR Publishing, 73-9.

Jensen, S.Q., 2011. Othering, identity formation and agency. Qualitative Studies 2(2), 63-78. 
Jodin, A., 1957. Les problèmes de la civilisation du vase campaniforme au Maroc [The problems of the Bell Beaker civilisation in Morocco]. Hespéris 44, 353-60.

Juárez Martín, J.M. (ed.), 2010. El enterramiento en cueva artificial de La Molina (Lora de Estepa, Sevilla) [The artificial cave burial at La Molina (Lora de Estepa, Sevilla)]. Seville: Junta de Andalucía.

Kardong, K.V., 1999. Vertebrados: anatomía comparada, función, evolución [Vertebrates: comparative anatomy, function, evolution]. Madrid: McGraw-Hill.

Krzyszkowska, O., 1984. Ivory from hippopotamus tusk in the Aegean Bronze Age. Antiquity 58, 123-5.

Krzyszkowska, O., 1990. Ivory and Related Materials: An illustrated guide. London: Institute of Classical Studies.

Krzyszkowska, O., 1992. Aegean ivory carving: towards an evaluation of Late Bronze Age workshop material, in Ivory in Greece and the Eastern Mediterranean from the Bronze Age to the Hellenistic Period, ed. J.L. Fitton. London: British Museum Press, 25-44.

Laclau, E. \& C. Mouffe, 1984. Hegemony and Socialist Strategy. London: Verso.

Lamont, M. 1992. Money, Morals and Manners. Chicago (IL): University of Chicago Press.

Lamont, M., 2001. Culture and identity, in Handbook of Sociological Theory, ed J.H. Turner. New York (NY): Springer, 171-85.

Lefebvre, A., A. Marín-Arroyo, E. Álvarez-Fernández, et al., 2021. Interconnected Magdalenian societies as revealed by the circulation of whale bone artefacts in the Pyreneo-Cantabrian region. Quaternary Science Reviews 251, 106692.

Leisner, G. \& V. Leisner, 1943. Die Megalithgräber der Iberischen Halbinsel. Der Süden [The megalithic tombs of the Iberian Peninsula. The South]. (Römisch-Germanische Forschungen 17.) Berlin: Walter de Gruyter.

Liesau Von Lettow-Vorbeck, C., A. Banerjee \& J. O. Schwarz, 2011. Camino de las Yeseras' ivory collection: advances in analysis technology used in identifying raw material, in Yacimientos calcoliticos con campaniforme de la región de Madrid: nuevos estudios [Chalcolithic and Campaniform sites in the Madrid region: new studies], eds M.C. Blasco Bosqued, C. Liesau von Lettow-Vorbeck \& P. Ríos Mendoza. Madrid: Universidad Autónoma de Madrid, 381-6.

Liesau Von Lettow-Vorbeck, C. \& E. Moreno, 2012. Marfiles campaniformes de El Camino de las Yeseras (San Fernando de Henares, Madrid) [Campaniform ivories from El Camino de las Yeseras (San Fernando de Henares, Madrid)], in Elfenbeinstudien. Faszikel 1: Marfil y Elefantes en la Península Ibérica y el Mediterráneo, Actas del coloquio internacional en Alicante el 26 y 27 de noviembre 2008 [Ivory Studies, Fascicle 1: Ivory and Elephants in the Iberian Peninsula and the Mediterranean, Proceedings of the international colloquium in Alicante on 26 and 27 November 2008], eds A. Banerjee, J.A. López Padilla
\& T.X. Schuhmacher. (Iberia Archaeologica 16(1).) Darmstadt: Philipp von Zabern, 83-94.

Liesau Von Lettow-Vorbeck, C. \& T.X. Schuhmacher, 2012. Un taller de marfil en el yacimiento argárico de Fuente Álamo (Cuevas del Almanzora, Almería) [An ivory workshop at the Argaric site of Fuente Álamo (Cuevas del Almanzora, Almería).], in Elfenbeinstudien. Faszikel 1: Marfil y Elefantes en la Península Ibérica y el Mediterráneo, Actas del coloquio internacional en Alicante el 26 y 27 de noviembre 2008 [Ivory Studies, Fascicle 1: Ivory and Elephants in the Iberian Peninsula and the Mediterranean, Proceedings of the international colloquium in Alicante on 26 and 27 November 2008], eds A. Banerjee, J.A. López Padilla \& T.X. Schuhmacher. (Iberia Archaeologica 16(1).) Darmstadt: Philipp von Zabern, 121-38.

Lillios, K., 1999. Objects of memory: the ethnography and archaeology of heirlooms. Journal of Archaeological Method and Theory 6(3), 235-62.

Locke, M., 2008. Structure of ivory. Journal of Morphology 269(4), 423-50.

López Aldana, P., A. Pajuelo Pando, J.C. Mejías-García \& R. Cruz-Auñón Briones, 2015. Variabilidad funeraria en las sociedades del III milenio en el sector Señorío de Guzmán de Valencina-Castilleja (Sevilla) [Funerary variability in 3rd millennium societies in the Señorío de Guzmán sector of Valencina-Castilleja (Seville)], in Death as Archaeology of Transition: Thoughts and materials, eds L. Rocha, P. Bueno-Ramirez \& G. Branco. (BAR International series S2708.) Oxford: Archaeopress, 257-73.

López Padilla, J.A., 2012. Dinámica de producción y consumo de marfil en el sudeste y área centromeridional del levante peninsular entre ca. 2200 BC y ca. 1200 BC [Ivory production and consumption dynamics in the southeast and south-central area of the Levantine Peninsula between ca. 2200 BC and ca. 1200 BC], in Elfenbeinstudien. Faszikel 1: Marfil y Elefantes en la Península Ibérica y el Mediterráneo, Actas del coloquio internacional en Alicante el 26 y 27 de noviembre 2008 [Ivory Studies, Fascicle 1: Ivory and Elephants in the Iberian Peninsula and the Mediterranean, Proceedings of the international colloquium in Alicante on 26 and 27 November 2008], eds A. Banerjee, J.A. López Padilla \& T. X. Schuhmacher. (Iberia Archaeologica 16(1).) Darmstadt: Philipp von Zabern, 139-55.

López Padilla, J.A. \& M.S. Hernández Pérez, 2011. The Italian connection: production, circulation and consumption of objects made of ivory and bone in the western Mediterranean between ca. 1500 and ca. 1000 B.C., in Elfenbein und Archäologie [Ivory and archaeology], eds A. Banerjee \& C. Eckmann. Mainz: Schnell \& Steiner, 53-62.

Luciañez-Triviño, M., 2018. El marfil en la edad del cobre de la península ibérica. Una aproximación tecnológica, experimental y contextual a las colecciones ebúrneas del mega-sitio de Valencina de la 
Concepción - Castilleja de Guzmán (Sevilla) [Ivory in the Copper Age of the Iberian Peninsula. A technological, experimental and contextual approach to the ebony collections of the mega-site of Valencina de la Concepción - Castilleja de Guzmán (Seville).]. $\mathrm{PhD}$ dissertation, Seville University.

Luciañez-Triviño, M. \& L. García Sanjuán, 2016. Los marfiles del tholos de Montelirio [The ivories of the tholos of Montelirio], in Montelirio: Un Gran Monumento Megalítico de la Edad del Cobre [Montelirio. A great megalithic monument of the Copper Age], eds A. Fernández Flores, L. García Sanjuán \& M. Díaz-Zorita Bonilla. Seville: Junta de Andalucía, 245-71.

Luciañez-Triviño, M., L. García Sanjuán \& T.X. Schuhmacher, 2014. Restaurierung von archäologischem Elfenbein am Beispiel von vier chalkolithischen Elfenbeinobjekte aus der Siedlung von Valencina de la Concepción (Sevilla) [Restoration of archaeological ivory: example of four chalcolithic ivory objects from the settlement of Valencina de la Concepción (Seville)]. Restaurierung und Archäologie 6, 71-87.

MacGregor, A., 1985. Bone, Antler, Ivory and Horn. The technology of skeletal materials since the Roman period, London/Sydney: Croom Helm/Barnes \& Noble.

Maicas Ramos, R., 2007. Industria ósea y funcionalidad: neolítico y calcolítico en la Cuenca de Vera (Almería) [Bone Industry and Functionality: Neolithic and Chalcolithic in the Vera Basin (Almería)]. Madrid: Bibliotheca Praehistorica Hispana, Consejo Superior de Investigaciones Científicas, Instituto de Historia.

McGhee, R., 1977. Ivory for the Sea Woman: the symbolic attributes of a prehistoric technology. Canadian Journal of Archaeology/Journal Canadien d'Archéologie $1,141-9$.

Mora Molina, C., L. García Sanjuán, J. Peinado Cucarella \& D. Wheatley, 2013. Las estructuras de la Edad del Cobre del Sector PP4-Montelirio del sitio arqueológico de Valecia de la Concepción-Castilleja de Guzmán (Sevilla) [The Copper Age structures of the PP4-Montelirio Sector of the archaeological site of Valecia de la Concepción-Castilleja de Guzmán (Seville)], in El asentamiento prehistórico de Valencina de la Concepción (Sevilla): investigación y tutela en el 150 aniversario del descubrimiento de La Pastora [The prehistoric settlement of Valencina de la Concepción (Seville): research and guardianship on the 150th anniversary of the discovery of La Pastora], eds L. García Sanjuán, J.M. Vargas Jiménez, V. Hurtado Pérez, T. Ruiz Moreno \& R. Cruz-Auñón Briones. Seville: Universidad de Sevilla, 261-79.

Morgado Rodríguez, A., J.A. Lozano, L. García Sanjuán, M. Luciañez-Triviño, C.P. Odriozola, D. Lamarca Irisarri \& A. Fernández Flores, 2016. The allure of rock crystal in southern Iberian Copper Age: technical mastery and distinguished objects at Valencina de la Concepción (Seville, Spain). Quaternary International 424, 232-49.
Morillo León, J.M., C. Pau \& J. Guilaine, 2018. The proboscidean ivory adornments from the hypogeum of PadruJossu (Sanluri, Sardinia, Italy) and the Mediterranean Bell Beaker. Zephyrus 82, 35-63.

Murillo-Barroso, M. 2016a. El ámbar del tholos de Montelirio [Amber from the Montelirio tholos], in Montelirio: Un Gran Monumento Megalítico de la Edad del Cobre [Montelirio. A great megalithic monument of the Copper Age], eds A. Fernández Flores, L. García Sanjuán \& M. Díaz-Zorita Bonilla. Seville: Junta de Andalucía, 311-44.

Murillo-Barroso, M., 2016b. El oro del tholos de Montelirio en el contexto de la tecnología áurea de Valencina [The gold of the Montelirio tholos in the context of Valencina's golden technology], in Montelirio: Un Gran Monumento Megalítico de la Edad del Cobre [Montelirio. A great megalithic monument of the Copper Age], eds A. Fernández Flores, L. García Sanjuán \& M. Díaz-Zorita Bonilla. Seville: Junta de Andalucía, 285-309.

Nocete Calvo, F., G. Queipo De Llano, R. Sáenz, et al., 2008. The smelting quarter of Valencina de la Concepción (Seville, Spain): the specialised copper industry in a political centre of the Guadalquivir valley during the third millennium BC (2750-2500 BC). Journal of Archaeological Science 35, 717-32.

Nocete Calvo, F., J.M. Vargas Jiménez, T.X. Schuhmacher, A. Banerjee \& W. Dindorf, 2013. The ivory workshop of Valencina de la Concepción (Seville, Spain) and the identification of ivory from Asian elephant on the Iberian Peninsula in the first half of the 3rd millennium BC. Journal of Archaeological Science 40(3), 1579-92.

Obermaier, H., 1919. El dolmen de Matarrubilla (Sevilla) [The dolmen of Matarrubilla (Sevilla)]. (Comisión de investigaciones Paleontológicas y Prehistóricas 26.) Madrid: Museo nacional de Ciencias Naturales.

Odriozola Lloret, C. \& L. García Sanjuán, 2013. Las cuentas de collar de piedra verde de Matarrubilla (Valencinadela Concepción (Sevilla) [Green stone necklace beads from Matarrubilla (Valencina d ela Concepción (Seville)], in El asentamiento prehistórico de Valencina de la Concepción (Sevilla): investigación y tutela en el 150 aniversario del descubrimiento de La Pastora [The prehistoric settlement of Valencina de la Concepción (Seville): research and guardianship on the 150th anniversary of the discovery of La Pastora], eds L. García Sanjuán, J.M. Vargas Jiménez, V. Hurtado Pérez, T. Ruiz Moreno \& R. Cruz-Auñón Briones. Seville: Universidad de Sevilla, 485-93.

Ortega Gordillo, M.J., 2015. Memoria final de la actividad arqueológica preventiva en la Avenida de Andalucía esquina a la calle clara Campoamor (Valencina de la Concepción, Sevilla) [Final report on the preventive archaeological activity in Avenida de Andalucía on the corner of Calle Clara Campoamor (Valencina de la Concepción, Seville)], unpublished excavation report. 
Pajuelo Pando, A., 2016. Los restos de animales de Montelirio [The animal remains of Montelirio], in Montelirio: Un Gran Monumento Megalítico de la Edad del Cobre [Montelirio. A great megalithic monument of the Copper Age], eds A. Fernández Flores, L. García Sanjuán \& M. Díaz-Zorita Bonilla. Seville: Junta de Andalucía, 455-67.

Pascual Benito, J.L., 2012. El taller de marfil del Bronce Pleno de Mola d'Agres (Alicante) [The ivory workshop of the Bronze Age at Mola d'Agres (Alicante)], in Elfenbeinstudien. Faszikel 1: Marfil y Elefantes en la Península Ibérica y el Mediterráneo, Actas del coloquio internacional en Alicante el 26 y 27 de noviembre 2008 [Ivory Studies, Fascicle 1: Ivory and Elephants in the Iberian Peninsula and the Mediterranean, Proceedings of the international colloquium in Alicante on 26 and 27 November 2008], eds A. Banerjee, J.A. López Padilla \& T.X. Schuhmacher. (Iberia Archaeologica 16(1).) Darmstadt: Philipp von Zabern, 173-97.

Pau, C., J.M. Morillo León, J.A. Cámara Serrano \& F. Molina González, 2018. Los objetos de adorno en marfil del yacimiento del Cerro de la Vírgen (Orce, Granada) [Ivory ornaments from the Cerro de la Vírgen site (Orce, Granada).]. Complutum 29(2), 267-98.

Posac Mon, C., 1975. Los Algarbes (Tarifa). Una necrópolis de la Edad del Bronce [Los Algarbes (Tarifa). A necropolis of the Bronze Age]. Noticiario Arqueológico Hipánico 4, 87-119.

Poyato Holgado, C. \& A. Hernando Grande, 1988. Relaciones entre la Península Ibérica y el Norte de África: marfil y campaniforme [Relations between the Iberian Peninsula and North Africa: ivory and Bell Beaker]. in Actas del Congreso Internacional El Estrecho de Gibraltar (Ceuta 1987), Vol.1, ed E. Ripoll Perelló, Madrid: UNED, Ayuntamiento de Ceuta, Centro Asociado de la UNED en Ceuta, 317-29.

Rijkelijkhuizen, M., 2008. Handleidingvoor de determinatie van harde dierlijke materialen: Bot, gewei, ivoor, hoorn, schildpad, balei, hoef [Guide to the determination of hard animal materials: Bone, antler, ivory, horn, tortoise, baleen, hoof]. Amsterdam: Amsterdam University Press.

Robles Carrasco, S. \& M. Díaz-Zorita Bonilla, 2013. Análisis bioarqueológico de tres contextos-estructuras funerarias del Sector PP4-Montelirio del yacimiento de Valencina de la Concepción-Castilleja de Guzmán (Sevilla) [Bioarchaeological analysis of three funerary structure contexts in Sector PP4-Montelirio of the site of Valencina de la Concepción-Castilleja de Guzmán (Sevilla)], in El asentamiento prehistórico de Valencina de la Concepción (Sevilla): investigación y tutela en el 150 aniversario del descubrimiento de La Pastora, eds L. García Sanjuán, J.M. Vargas Jiménez, V. Hurtado Pérez, T. Ruiz Moreno \& R. Cruz-Auñón Briones. Seville: Universidad de Sevilla, 369-86.

Rogerio-Candelera, M.A., L. Karen Herrera, A.Z. Millar, et al., 2013. Red pigments used in burial practices at the Copper Age site of Valencina de la Concepción (Sevilla, Spain): characterisation and social dimension. Journal of Archaeological Science 40, 279-90.

Santana Falcón, I., 1991. Excavación arqueológica de emergencia en un dolmen del término municipal de Castilleja de Guzmán (Sevilla) [Emergency archaeological excavation of a dolmen in the municipality of Castilleja de Guzmán (Seville).]. Anuario Arqueológico de Andalucía 1989, 446-9.

Schubart, H., 1990. Almizaraque y Zambujal como plazas portuarias de la Edad del Cobre [Almizaraque and Zambujal as Copper Age port cities]. Verdolay: Revista del Museo Arqueológico de Murcia 2. Homenaje a D. Emeterio Cuadrado Díaz, 19-25.

Schuhmacher, T.X., 2012a. El marfil en España desde el Calcolítico al Bronce Antiguo. Resultados de un proyecto de investigación interdisciplinar [Ivory in Spain from the Chalcolithic to the Early Bronze Age. Results of an interdisciplinary research project], in Elfenbeinstudien. Faszikel 1: Marfil y Elefantes en la Península Ibérica y el Mediterráneo, Actas del coloquio internacional en Alicante el 26 y 27 de noviembre 2008 [Ivory Studies, Fascicle 1: Ivory and Elephants in the Iberian Peninsula and the Mediterranean, Proceedings of the international colloquium in Alicante on 26 and 27 November 2008], eds A. Banerjee, J.A. López Padilla \& T.X. Schuhmacher. (Iberia Archaeologica 16(1).) Darmstadt: Philipp von Zabern, 45-68.

Schuhmacher, T.X., 2012b. Elfenbeinstudien, Faszikel 2: Chalkolithische und frühbronzezeitliche Elfenbeinobjekte auf der Iberischen Halbinsel. Studien zu Herkunft, Austausch, Verarbeitung und sozialer Bedeutung von Elfenbein [Ivory Studies, Fascicle 2: Chalcolithic and Early Bronze Age Ivory Objects on the Iberian Peninsula. Studies on the origin, exchange, processing and social significance of ivory]. (Iberia Archaeologica 16(2).) Darmstadt/Mainz: Philipp von Zabern.

Schuhmacher, T.X., 2013. Ivory from Sobreira de Cima (Vidigueira, Beja), in Sobreira de Cima. Necrópole de hipogeus do Neolítico (Vidigueira, Beja) [Sobreira de Cima. Necropolis of Neolithic hypogeus (Vidigueira, Beja)], ed. A.C. Valera. (ERA monografica 1.) Lisbon: Núcleo de Investigação Arqueológica (NIA), 97-9.

Schuhmacher, T.X., 2016. Elefanten und Elfenbein auf der Iberischen Halbinsel und in Nordwestafrika. Interdisziplinäre Studien zu Austauschsystemen im 3. und der ersten Hälfte des 2. Jts. v. Chr. [Elephants and ivory on the Iberian Peninsula and in Northwest Africa. Interdisciplinary studies on exchange systems in the 3rd and first half of the 2nd century BC]. (Iberia Archaeologica 16(3).) Tübingen: Ernst Wasmuth Verlag.

Schuhmacher, T.X., 2017. Ivory exchange networks in the Chalcolithic of the Western Mediterranean, in Key Resources and Sociocultural Developments in the Iberian 
Crafting Idiosyncrasies. Early Social Complexity, Ivory and Identity-Making in Copper Age Iberia

Chalcolithic, eds M. Bartelheim, P. Bueno Ramirez \& M. Kunst. Tübingen: Library Publishing, 291-312.

Schuhmacher, T.X. \& A. Banerjee, 2012. Procedencia e intercambio de marfil en el Calcolítico de la Península Ibérica [Provenance and exchange of ivory in the Chalcolithic of the Iberian Peninsula]. Rubricatum: revista del Museu de Gavà 5, 289-98.

Schuhmacher, T.X., A. Banerjee, W. Dindorf, F. Nocete Calvo \& J.M. Vargas Jiménez, 2013a. Los marfiles del yacimiento de Valencina de la Concepción (Sevilla) en el contexto del Calcolítico del suroeste peninsular [The ivories from the Valencina de la Concepción site (Seville) in the context of the Chalcolithic period in the southwest of the Iberian Peninsula], in El asentamiento prehistórico de Valencina de la Concepción (Sevilla): investigación y tutela en el 150 aniversario del descubrimiento de La Pastora [The prehistoric settlement of Valencina de la Concepción (Seville): research and guardianship on the 150th anniversary of the discovery of La Pastora], eds L. García Sanjuán, J.M. Vargas Jiménez, V. Hurtado Pérez, T. Ruiz Moreno \& R. Cruz-Auñón Briones. Seville: Universidad de Sevilla, 495-510.

Schuhmacher, T.X., A. Banerjee, W. Dindorf, C. Sastri \& T. Sauvage, 2013b. The use of sperm whale ivory in Chalcolithic Portugal. Trabajos de Prehistoria 70(1), 185-203.

Schwab, C. \& C. Vercoutère, 2018. Les statuettes en ivoire gravettiennes d'Europe occidentale [Gravettian ivory statuettes of western Europe]. L'Anthropologie 122(3), 469-91.

Serra-Rafols, J. de C., 1925. cf. Elfenbein, Pyrenäenhalbinsel [Ivory, Iberian peninsula], in Reallexikon der Vorgeschichte [Encyclopaedia of prehistory], ed. M. Ebert. Berlin: Walter de Gruyter vol. 3, 87-8.

Siret, L., 1913. Questions de chronologie et d'ethnographie ibériques [Questions of Iberian chronology and ethnography]. Paris: Paul Geuthner.

Staszak, J., 2008. Other/otherness, in International Encyclopedia of Human Geography, eds R. Kitchin \& N. Thrift. Amsterdam: Elsevier Science, vol. 8, 43-7.

Tolksdorf, J.F., S. Veil, I. Kuzu, B. Ligouis, U. Staesche \& K. Breest, 2015. Ivory or bone? A report on practical experience determining material from the Mesolithic site Klein Breese (Northern Germany). Archaeological and Anthropological Science 7(3), 1-10.

Tournavitou, I., 1995. The Mycenaean ivories from the Artemision at Delos. Bulletin de Correspondance Hellénique 119(2), 479-527.

Valera, A.C., 2010. Marfim no recinto calcolítico dos Perdigões (1): lúnulas, fragmentação e ontologia dos artefactos [Ivory in the Chalcolithic enclosure of Perdigões (1): lunulae, fragmentation and ontology of artefacts], Apontamentos de Arqueologia $e$ Património (5), 31-42.

Valera, A.C. 2020. Interação e recursos exóticos na Pré-História Recente: a circulação e consumo de marfim em Portugal [Interaction and exotic resources in late prehistory; circulation and consumption of ivory in Portugal], in Mobilidades na Pré-história: Pessoas, recursos, objetos, sítios e territórios [Mobilities in Prehistory: People, resources, objects, sites and territories], eds R. Vilaça \& R. Simas de Aguiar. Coimbra: Coimbra University Press, 135-81.

Valera, A.C., T.X. Schuhmacher \& A. Banerjee, 2015. Ivory in the Chalcolithic enclosure of Perdigões (South Portugal): the social role of an exotic raw material. World Archaeology 47(3), 390-413.

Vargas Jiménez, J.M., F. Nocete Calvo \& M. Ortega Gordillo, 2010. Excavaciones arqueológicas en la parcela del nuevo IES de Valencina de la Concepción (Sevilla) [Archaeological excavations in the plot of the new secondary school (IES) in Valencina de la Concepción (Seville)]. Anuario Arqueológico de Andalucía 2005, 3340-56.

Vargas Jiménez, J.M., F. Nocete Calvo \& T.X. Schuhmacher, 2012. Contextos de producción de marfil en Valencina de la Concepción (Sevilla) [Contexts of ivory production in Valencina de la Concepción (Seville)], in Elfenbeinstudien. Faszikel 1: Marfil y Elefantes en la Península Ibérica y el Mediterráneo, Actas del coloquio internacional en Alicante el 26 y 27 de noviembre 2008 [Ivory Studies, Fascicle 1: Ivory and Elephants in the Iberian Peninsula and the Mediterranean, Proceedings of the international colloquium in Alicante on 26 and 27 November 2008], eds A. Banerjee, J.A. López Padilla \& T. X. Schuhmacher. (Iberia Archaeologica 16(1).) Darmstadt: Philipp von Zabern, 69-81.

Virág, A., 2012. Histogenesis of the unique morphology of proboscidean ivory. Journal of Morphology 273, 1406-23.

Walker, M., S. Johnsen, S. O. Rasmussen, et al., 2009. Formal definition and dating of the GSSP (Global Stratotype Section and Point) for the base of the Holocene using the Greenland NGRIP ice core, and selected auxiliary records. Journal of Quaternary Science 24, 3-17.

Wheatley, D., K. Strutt, L. García Sanjuán, J. Peinado Cucarella \& C. Mora Molina, 2012. New evidence on the spatial organisation of the Valencina de la Concepción Copper Age settlement: the geophysics between La Pastora and Montelirio. Trabajos de Prehistoria 69(1), 65-79.

Wolf, S. \& C. Heckel, 2018. Ivory ornaments of the Aurignacian in western Europe: case studies from France and Germany. L'Anthropologie 122(3), 348-73.

\section{Author biographies}

Miriam Luciañez-Triviño is a post-doctoral research fellow between the University of the Basque Country UPV/EHU (Spain) and Eberhard-Karls-Universität Tübingen (Germany). She specializes in the study of prehistoric osseous materials, particularly ivory, which she approaches 
through morphological and technical study, experimental archaeology and scientific analysis.

Leonardo García Sanjuán is a Full Professor in Prehistory at the Department of Prehistory and Archaeology, University of Seville (Spain). His current research focuses on social complexity, burial practices, megalithic monumentality and landscape studies. He has carried out fieldwork throughout southern Spain, including major sites such as Antequera and Valencina.

Thomas X. Schuhmacher is a Senior Research Fellow at the German Archaeological Institute, Madrid branch. His research work focuses on the study of Iberian Later Prehistory, including an Iberian-scope analysis of ivory as well as ongoing fieldwork at the Valencina Copper Age mega-site. 